Florida International University

FIU Digital Commons

FIU Electronic Theses and Dissertations

University Graduate School

9-11-1998

\title{
The effect of cooperative learning on the attitudes toward science and the achievement of students in a non-science majors' general biology laboratory course at an urban community college
}

Genevieve C. Chung-Schickler

Florida International University

DOI: $10.25148 /$ etd.FI14060830

Follow this and additional works at: https://digitalcommons.fiu.edu/etd

Part of the Higher Education Commons

\section{Recommended Citation}

Chung-Schickler, Genevieve C., "The effect of cooperative learning on the attitudes toward science and the achievement of students in a non-science majors' general biology laboratory course at an urban community college" (1998). FIU Electronic Theses and Dissertations. 2360.

https://digitalcommons.fiu.edu/etd/2360

This work is brought to you for free and open access by the University Graduate School at FIU Digital Commons. It has been accepted for inclusion in FIU Electronic Theses and Dissertations by an authorized administrator of FIU Digital Commons. For more information, please contact dcc@fiu.edu. 
FLORIDA INTERNATIONAL UNIVERSITY

Miami, Florida

THE EFFECT OF COOPERATIVE LEARNING ON THE ATTITUDES TOWARD SCIENCE AND THE ACHIEVEMENT OF STUDENTS IN A NON-SCIENCE MAJORS' GENERAL BIOLOGY LABORATORY COURSE AT AN URBAN COMMUNITY COLLEGE

A dissertation submitted in partial satisfaction of the requirements for the degree of DOCTOR OF EDUCATION

IN HIGHER EDUCATION INSTRUCTION by

Genevieve C. Chung-Schickler 1998 
To: Acting Dean Robert Vos

College of Education

This dissertation, written by Genevieve C. Chung-Schickler, and entitled "The Effect of Cooperative Learning on the Attitudes Toward Science and the Achievement of Students in a Non-Science Majors' General Biology Laboratory Course at an Urban Community College", having been approved in respect to style and intellectual content, is referred to you for your judgement.

We have read this dissertation and recommend that it be approved.

Luis A. Martinez-Perez

George E. O'Brien

Janice R. Sandiford, Major Professor

Date of Defense: September 11, 1998

The dissertation of Genevieve C. Chung-Schickler is approved.

Acting Dean Robert Vos

College of Education

Dr. Richard L. Campbell

Dean of Graduate Studies

Florida International University, 1998 
OCOPYRIGHT 1998 by Genevieve C. Chung-Schickler

All rights reserved 
I dedicate this dissertation to my husband, Dr. Robert D. Schickler. His support throughout my graduate studies made it possible to complete my dissertation. The understanding of my children, Sarah and Michael, also enabled me to finish my doctorate expeditiously. 


\section{ACKNOWLEDGEMENTS}

The support and input of several individuals were critical to the development and completion of my doctoral studies and this research project. My major professor, Dr. Sandiford, provided incredible assistance. Her valuable comments, timeliness, and skill in negotiating the challenges of a dissertation's approval enabled me to enjoy this research project. Dr. O'Brien provided insightful comments which helped me write a clearer and more thoughtful dissertation. Dr. Johnson's guidance through the statistical analyses of the research data made it a pleasurable journey. Dr. Wright and K. Mascetti provided important information about the urban community college at which the study was performed. Dr. Fraser generously granted permission to use the Test of ScienceRelated Attitudes. Dr. Martinez-Perez's vote of confidence provided support throughout the doctoral process. I am deeply indebted to all these educators. 


\section{ABSTRACT OF THE DISSERTATION PROPOSAL}

\section{THE EFFECT OF COOPERATIVE LEARNING ON THE ATTITUDES TOWARD SCIENCE AND THE ACHIEVEMENT OF STUDENTS IN A NON-SCIENCE MAJORS' GENERAL BIOLOGY LABORATORY COURSE}

AT AN URBAN COMMUNITY COLLEGE By Genevieve C. Chung-Schickler Florida International University, 1998 Miami, Florida Professor Janice Sandiford, Major Professor

The purpose of this study was to evaluate the effect of cooperative learning strategies on students' attitudes toward science and achievement in BSC 1005L, a non-science majors' general biology laboratory course at an urban community college. Data were gathered on the participants' attitudes toward science and cognitive biology level pre and post treatment in BSC 1005L. Elements of the Learning Together model developed by Johnson and Johnson and the Student Team-Achievement Divisions model created by Slavin were incorporated into the experimental sections of BSC 1005L.

Four sections of BSC 1005L participated in this study. Participants were enrolled in the 1998 spring (January) term. Students met weekly in a two hour 
laboratory session. The treatment was administered to the experimental group over a ten week period. A quasi-experimental pretest-posttest control group design was used. Students in the cooperative learning group $\left(n_{1}=27\right)$ were administered the Test of Science-Related Attitudes (TOSRA) and the cognitive biology test at the same time as the control group $\left(n_{2}=19\right.$ ) (at the beginning and end of the term).

Statistical analyses confirmed that both groups were equivalent regarding ethnicity, gender, college grade point average and number of absences. Independent sample t-tests performed on pretest mean scores indicated no significant differences in the TOSRA scale two or biology knowledge between the cooperative learning group and the control group. The scores of TOSRA scales: one, three, four, five, six, and seven were significantly lower in the cooperative learning group. Independent sample t-tests of the mean score differences did not show any significant differences in posttest attitudes toward science or biology knowledge between the two groups. Paired t-tests did not indicate any significant differences on the TOSRA or biology knowledge within the cooperative learning group. Paired th-tests did show significant differences within the control group on TOSRA scale two and biology knowledge. ANCOVAs did not indicate any significant differences on the post mean scores of the TOSRA or biology knowledge adjusted by differences in the pretest mean scores. Analysis of the research data did not show any significant correlation between attitudes toward science and biology knowledge. 


\section{TABLE OF CONTENTS}

\section{Chapter}

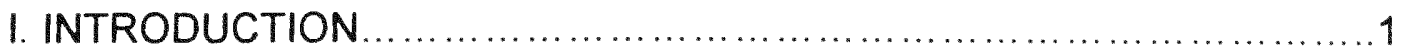

Background to the Problem...................................... 1

Community college students ................................. 1

Science education........................................... 2

Science for all students in higher education.................... 3

Statement of the Problem............................................. 5

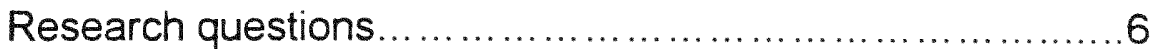

Hypotheses ................................................... 6

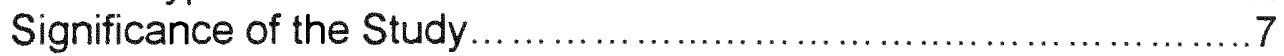

Attitudes and achievement................................. 7

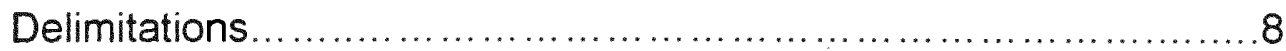

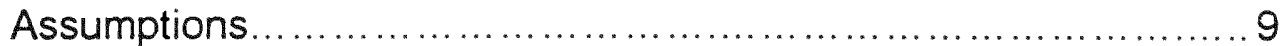

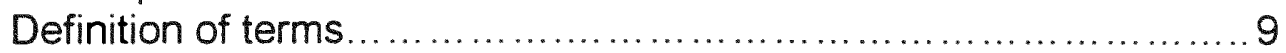

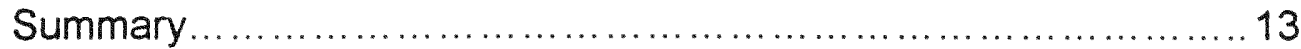

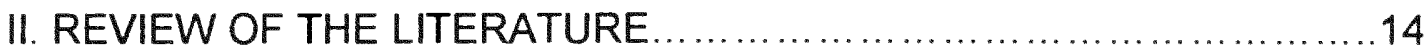

Changing higher education paradigm ............................. 14

Cooperative learning ........................................... 15

Description of cooperative learning ........................ 15

Learning Together model..................................... 16

Student Teams-Achievement Divisions (STAD) model ........17

Types of cooperative learning groups........................18

Cooperative learning and higher education......................... 19

Benefits of effective cooperative learning in higher education 20 Cooperative learning in colleges and universities................... 21

Achievement in colleges and universities.................. 21

Attitude in colleges and universities.......................... 23

Cooperative learning in community colleges........................ 25

Achievement in community colleges........................ 25

Attitude in community colleges........................... 26

Essential components of cooperative learning in higher education.. 26 Cooperative learning in the higher education science laboratory.... 32

Science-related attitudes ......................................... 33

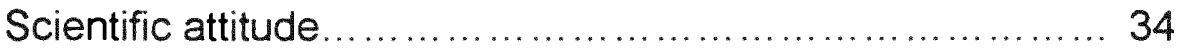

Attitudes toward science ................................. 34

Instruments for measuring attitudes toward science.......... 35

Determining biology achievement.............................. 36

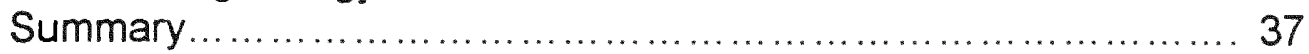




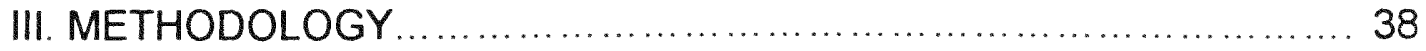

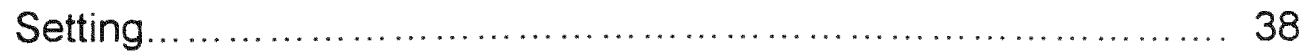

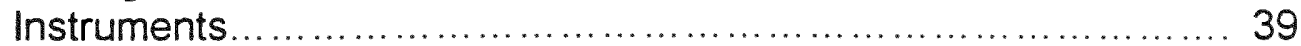

Test of Science-Related Attitudes (TOSRA) ................. 39

Test of Science-Related Attitudes instrument validity......... 40

Test of Science-Related Attitudes instrument reliability....... 42

Cognitive biology test.................................... 42

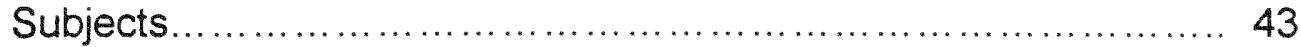

Statistical procedure and analyses ............................. 44

Data collection........................................... 44

Statistical analyses..................................... 44

Design....................................................... 45

BSC $1005 \mathrm{~L}$ cooperative learning sections................ 45

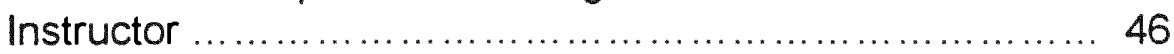

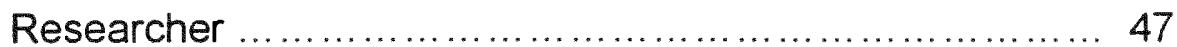

Students ............................................... 48

Student assessment.................................... 49

BSC $1005 \mathrm{~L}$ experimental sections....................... 49

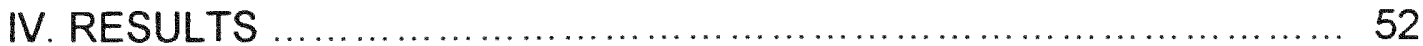

Analysis of the sample ...................................... 52

Analysis of the research data.................................. 56

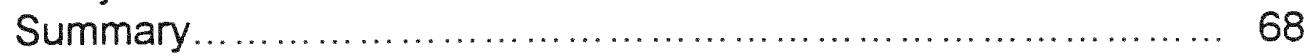

V. SUMMARY, DISCUSSION, CONCLUSIONS \& RECOMMENDATIONS. 72

Discussion of the results........................................ 72

Conclusions ................................................... 75

Instructor experience .................................... 76

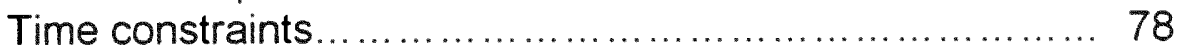

Recommendations .............................................. 79

Implications for future research ............................. 81

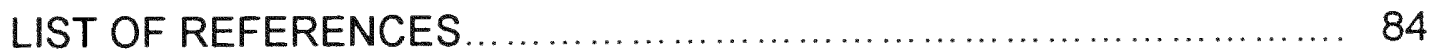

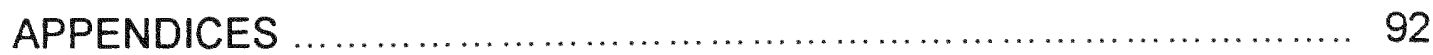

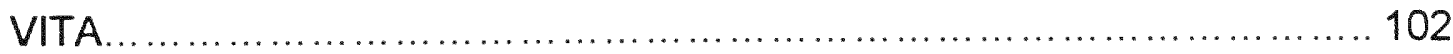




\section{LIST OF TABLES}

Table

Page

1. Schedule cooperative learning section........................... 51

2. Profile of study participants ................................... 55

3. Pretest mean scores by group ................................ 58

4. Mean score differences by group ............................... 61

5. Pre, post, differences mean scores within the cooperative learning

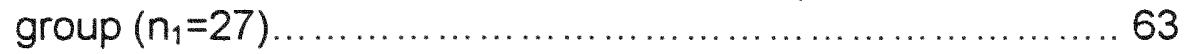

6. Pre, post, differences mean scores within the control group $\left(n_{2}=19\right) .65$

7. ANCOVA of the post scores adjusted by the pre scores, absences, gender, grade point average, and ethnicity between groups...67 


\section{CHAPTER ONE}

\section{Background to the Problem}

\section{Community college students}

Community colleges have become an important site for higher education. As of 1996 there were 1,113 community colleges in the United States. An analysis of the $1994-1995$ academic year indicated that approximately 9.1 million credit students and approximately 5 million noncredit students attended American community colleges during the 1994 fall term (Phillippe, 1997). This represented $45 \%$ of all undergraduates in the United States.

During the 1960's research identified several common characteristics of community college students. Many graduated from high school with (a) inadequate basic skills, (b) poor study habits, (c) limited motivation, (d) a C or lower average, (e) no home support for continuing education, and (f) unclear and impractical goals (Roueche and Roueche, 1993). Thirty years later many community college students are still limited by insufficient academic skills, scholastic achievement, motivation, social support, and unrealistic goals. Older students must often maintain a full-time job, coursework requirements, family commitments, and financial responsibilities. Many community college students are the first members in their families to attempt higher education. Their concepts of what their roles and goals in college should be are often illdefined. Entering college is overwhelming. Obler, Arnold, Sigala, and Umbdenstock (1991) describes community college students as "inexperienced 
adult learners". They do not have the cognitive learning strategies (Weinstein, Meyer, and Van Mater Stone, 1994) or supportive relationships crucial to college success.

The door to higher education has been open for more than twenty years. However, access does not guarantee opportunity. Access has enabled more diverse population segments to enter college. However, true opportunities in higher education have been more complicated and difficult to achieve.

It is not just having the right to try. Educational opportunity depends on community colleges' abilities to understand their students, to design curriculum and instruction to address their needs, and to employ faculty who embrace philosophically and operationally this changing array of challenges. (Roueche and Roueche, 1993, p. 33)

Science education

Three broad goals for science education have been identified. They are (a) understanding scientific knowledge, (b) understanding and using scientific methods, and (c) promoting personal-social development (Bybee and DeBoer, 1994, p. 380).

These goals can be categorized into what is to be learned and the purposes to which science knowledge, methods, and applications are put to use. The domain of what is to be learned encompasses (a) acquisition of scientific knowledge, (b) learning the processes or methodologies of the sciences, and (c) understanding the applications of science. The realm of purposes to which knowledge, methods, and applications are applied refers to (a) personal and 
social development, (b) knowledge of scientific facts and principles to advance scientific frontiers, and (c) scientific methods and their application which develop the intellect, help deal with social problems, and enables expansion of scientific knowledge. It is these purposes which justifies science education for all students.

Science for all students in higher education

\section{Non-science majors' biology lecture courses.}

Biology is relevant to the lives of all students, not only those students planning careers in science. An appreciation of biology will help students better understand the physical world in which they live. As science advances, the importance and practical applicability of biological concepts to everyday life increases dramatically. Research suggests that enhancing biology comprehension will enable students to interpret what they read, learn, and make informed decisions about science issues that will affect their lives. They will be better equipped to participate effectively in a global community.

BSC 1005 is an introductory general biology course at an urban community college. It is designed primarily for non-science majors' students. The intent of this course is to give students an understanding of the modern principles of biology, while focusing on the nature and activities of living organisms. It is to be taken concurrently with BSC 1005L - general biology laboratory. The major topics covered in this lecture course are: (a) scientific thinking, (b) origin of life and evolution, (c) chemistry of life, (d) cells and cellular architecture, (e) biochemistry, (f) cellular respiration, ( $g$ ) photosynthesis, (h) mitosis and meiosis, (i) animal development, and (j) genetics. 


\section{Non-science majors' biology laboratory courses.}

The laboratory became a core of the science learning process during the 1960s. Shulman and Tamir (1973) classified the goals for science laboratory instruction as (a) stimulating and maintaining interest, attitude, curiosity, and open-mindedness in science, (b) promoting creative thinking and problem-solving skills, (c) encouraging scientific thinking, (d) facilitating intellectual ability and conceptual understanding, and (e) practicing the basics of the scientific method (e. g. designing and executing investigations, observations, recording data, and analyzing and interpreting results).

"Research on learning suggests that experiences with real materials are an essential element in cognitive development" (Lunetta and Hofstein, 1991, p. 126). Non-science majors' biology laboratory courses offer college students an opportunity to experience the excitement of biology. As they study living organisms they can more authentically learn biology instead of learning about biology.

BSC $1005 \mathrm{~L}$ is an introductory general biology laboratory course at an urban community college. It is designed primarily for non-science majors' students. It is to be taken concurrently with BSC 1005 - general biology. The major topics covered in this laboratory course are: (a) the scientific method, (b) compound microscopes, (c) cell chemistry, (d) enzymes, (e) bacteria and paramecium, (f) cellular respiration, (g) plant anatomy, (h) plant physiology, (i) heredity, (j) cell division: mitosis and meiosis, (k) genetics, (l) comparative anatomy, (m) human physiology, and (n) environmental science and ecology. 
Non-science majors' biology courses and the university student.

Biology is difficult to learn because it consists of numerous unfamiliar concepts with complex relationships. Klionsky (1998) notes that university students in introductory general biology courses often fail to understand critical concepts. Even those students who are able to grasp these essential ideas are unable to make the transition from comprehension to application.

Non-science majors' biology courses and the community college student.

Since admission requirements are more rigorous at four year institutions it is not unreasonable to assume that if university students have difficulty mastering an introductory general biology course then community college students would also experience the same phenomenon. Saunders and Dickinson (1979) investigated the achievement of community college students in a general biology lecture mode versus a general biology lecture-laboratory mode. Their findings suggest that community colleges need to provide opportunities for active student involvement in the learning process in order to enhance academic achievement and attitudes toward science.

\section{Statement of the Problem}

All students at the institution where the study was conducted are required to fulfill a natural science requirement for graduation. BSC 1005 - general biology and BSC $1005 \mathrm{~L}$ - general biology laboratory are the courses most frequently chosen. During the 1996-1997 academic year there were 2,207 students enrolled in BSC 1005L. However, only 1,484 (67.24\%) successfully completed the course with a grade of C or higher (K. Mascetti, personal communication, May 14,1998). 


\section{Research questions.}

The following research questions were addressed:

1. Will participation in the BSC $1005 \mathrm{~L}$ cooperative learning sections at an urban community college significantly increase students' positive attitudes toward science?

2. Will participation in the BSC $1005 \mathrm{~L}$ cooperative learning sections at an urban community college significantly increase students' achievement in BSC 1005L?

3. Will those students with higher positive attitudes toward science perform better on a cognitive biology instrument than those students with low attitudes toward science?

\section{Hypotheses.}

The following research hypotheses were tested:

1. Students who participate in the BSC $1005 \mathrm{~L}$ cooperative learning sections at an urban community college will perform significantly better on an instrument designed to measure attitudes toward science than those students who do not participate in the cooperative learning sections.

2. Students who participate in the BSC $1005 \mathrm{~L}$ cooperative learning sections at an urban community college will perform significantly better on a cognitive biology instrument than those students who do not participate in the cooperative learning sections. 
3. Students with higher positive attitudes toward science will perform significantly better on a cognitive biology instrument than those students with low attitudes toward science (George, 1994).

\section{Significance of the study}

\section{Attitudes and achievement.}

"Attitudes and achievement are inextricably linked and that, therefore, the person interested in a student's cognitive achievement must also be concerned with affective factors" ( Schibeci, 1983, p. 595). Consideration of our student demographics indicates which teaching strategies may be most effective (Abraham, 1989). Female, African-American, and Hispanic students are more comfortable with the Cooperative Learning model (Cohen, 1990). A correlation has been documented between a student's attitudes toward science and their achievement in science (George, 1994; Germann, 1988; Koballa and Crawley, 1985; Shrigley, 1983; Wilson 1983). Research has shown that attitudes toward science and science achievement are significantly improved when a learning environment is created that is inclusive, cooperative, challenging, and supportive (Slavin, 1990).

Ninety two publications regarding cooperative learning in higher education were reviewed. Research suggests a correlation between this instructional approach and a positive attitude toward the subject being studied (Aronson and Patnoe, 1997; Cooper and Mueck, 1990; Johnson, Johnson, and Smith, 1990; Johnson, Johnson, Stanne, and Garibladi, 1989). Results indicate that 
cooperative learning may be a powerful tool in positively affecting student attitudes and achievement.

If we are to enable more community college students to successfully master BSC 1005L then we must reconsider how it is designed. Mason (1992) concluded that science educators can encourage meaningful learning and conceptual restructuring by redesigning their instruction methods. Our focus in the BSC $1005 \mathrm{~L}$ has been on science content. It is time to consider incorporating more appropriate pedagogy into this laboratory course. Other community colleges are enlarging their perspective of teaching beyond student mastery of course content. Institutions such as Seattle Central Community College have created programs in which students actively build their knowledge while working cooperatively with classmates to nurture student attitudes, competencies, talents, and resourcefulness (Tinto and Russo, 1994).

\section{Delimitations}

This study had the following delimitations:

1. The generalizability of the results is limited to the population under discussion.

2. The research does not correlate the effectiveness of cooperative learning strategies with variables such as student status (full-time or part-time), employment status (full-time or part-time), number of precollege courses required or completed, or the number of college credits taken at the same time as BSC $1005 \mathrm{~L}$. 


\section{Assumptions}

The study had the following assumptions:

1. Implementation of cooperative learning strategies in BSC $1005 \mathrm{~L}$ would have a positive effect on students' attitudes toward science.

2. To increase students' achievement in BSC 1005L, faculty must consider alternative instructional methods.

3. Implementation of the cooperative learning strategies in BSC $1005 \mathrm{~L}$ would have a positive effect on students' achievement in BSC 1005L.

\section{Definition of terms}

Active learning.

An educational approach in which students are self-motivated to take more responsibility for their learning, seek out the information that they require, and are able to evaluate their academic progress (Foyle, 1995).

\section{Attitudes toward science.}

Refers to a negative or positive feeling about science. This term can include attitudes to science; attitudes to a science issue; attitudes to science instruction; attitudes to science careers; attitudes toward scientists; and enjoyment, interest, or satisfaction in science.

BSC 1005.

Abbreviation for the general biology lecture course for non-science majors at an urban community college. 
BSC 1005L.

Abbreviation for the general biology laboratory course for non-science majors at an urban community college.

Concept map.

An instructional tool used to visualize the hierarchy and interrelationships between concepts. It has been used in science education to help students identify misconceptions, organize concept knowledge, and facilitate subject mastery (Mason, 1992).

Drill and review dyad.

A cooperative learning technique in which student pairs focus on problemsolving strategies and procedures. An explainer describes step by step how to solve a problem. A checker verifies that the information is accurate, encourages, and coaches as needed (Johnson, Johnson, and Smith, 1991b).

Group task.

Work which requires resources that no one individual has. Therefore, no one person can solve the problem or achieve the task objectives without assistance from the other group members.

Group reward.

A reward given to a group which has been earned by the individual achievement of all individual members.

Heterogeneous team (group).

A term used to refer to student groups of different abilities, ethnicity, and/or gender. These teams are formed to accomplish academic goals. 


\section{Jigsaw.}

A small group strategy where students are assigned sections of academic material to master. Students collaborate with colleagues working on the same content to become an "expert" on that knowledge. They then return to their original groups to teach those members (Aronson and Patnoe, 1997).

\section{Jigsaw II.}

A cooperative learning approach in which all students have the same resources. Individual group members are assigned a topic in which they will become an expert. Experts learn by working together on the same topic. They teach the concepts to others when they return to their original groups. Content mastery is evaluated by individual quiz achievement (Slavin, 1991a).

\section{Learning Together model.}

A cooperative learning method developed by David and Roger Johnson. Its' five basic components are: positive interdependence, face-to-face interaction, individual accountability, social skills, and group processing. This instructional approach uses four or five member heterogeneous teams (Johnson, Johnson, and Smith, 1991b).

\section{Metacognition.}

Thinking about thinking. Understanding one's learning needs, what academic tasks require, and which strategy to use to accomplish an academic goal. Successful learning requires that students can set meaningful goals, generate and maintain personal motivation, allocate resources appropriately, 
develop a repertoire of cognitive learning strategies, and accurately evaluate their progress (Weinstein, Meyer, and Van Mater Stone, 1994).

Science laboratory work.

A type of practical work which takes place in a purposefully designed environment where students participate in planned learning experiences and interact with materials in order to observe and comprehend scientific phenomena (Nuffield Foundation, 1977a).

Scientific attitude.

Those qualities which are believed to be necessary for a scientist to accomplish their professional responsibilities. This term can include curiosity, open-mindedness, creativity, critical-mindedness, skepticism, objectivity, rationality, a willingness to suspend judgement until all the evidence is weighed, honesty, and humility.

\section{Student Teams-Achievement Divisions (STAD).}

Robert Slavin created the STAD technique. Group goals and individual accountability are critical components of this cooperative learning approach.

Heterogeneous student learning teams are presented with cognitive information by an instructor. Then these teams work together to help each other master the material. Quizzes are taken individually. Team rewards can be earned by individual quiz achievement (Slavin, 1991b).

TOSRA (Test of Science-Related Attitudes).

Abbreviation for the Test of Science-Related Attitudes described by Fraser (1978). This instrument was based on Klopfer's (1976) classification of the 
attitudinal aims for science education. The TOSRA attempts to measure a respondent's attitude about (a) the social implications of science, (b) the normality of scientists, (c) scientific inquiry and the adoption of scientific attitudes, (d) their enjoyment of science lessons, (e) their leisure interest in science, and (f) their career interest in science.

Think-pair-share.

Students think silently about an instructor assigned topic. After individual contemplation students pair up with another student to discuss that topic. This cooperative learning technique provides students with opportunities to reflect, elaborate, and mentor critical thinking (Slavin, 1990).

\section{Summary}

The purpose of this study was to evaluate the effect of cooperative learning strategies on students in BSC 1005L, a non-science majors' general biology laboratory course at an urban community college. The variables of interest were students' attitudes toward science and achievement in BSC 1005L. Components of the Learning Together model by David and Roger Johnson and the Student Team-Achievement Divisions model by Robert Slavin were incorporated into this introductory general biology laboratory course.

This study provided important data to the institution where the research was conducted. Analysis of the information will facilitate the planning of future non-science majors' laboratory courses. Insights gained from this study will also add to an understanding of how cooperative learning can be best utilized in community college courses. 


\section{CHAPTER TWO}

Review of the Literature

The purpose of this study involved two aspects: first to incorporate cooperative learning into a non-science majors' biology laboratory course and second to evaluate the effectiveness of these strategies on community college students. Positively increasing students' attitudes toward science may increase students' science achievement.

The cooperative learning strategies were selected by reviewing science education, cooperative learning, small group development, science laboratory, and attitudinal theory and research resources. It was determined that the most appropriate cooperative learning techniques for BSC $1005 \mathrm{~L}$ would be a combination of various components of (a) the Learning Together model developed by David and Roger Johnson and (b) the Student Team-Achievement Divisions model created by Robert Slavin. Content, organization, and delivery methods were integrated into the experimental sections of BSC $1005 \mathrm{~L}$ at an urban community college.

\section{Changing higher education paradigm}

College teaching is evolving to a structure that includes more pedagogical theory and research. The recognition that an increasing number of community college students are inexperienced adult learners has initiated an instructional shift. More instructors are incorporating active learning techniques into their college courses (Cooper, 1990). Students are being taught metacognition 
strategies (Weinstein, Meyer, and Van Mater Stone, 1994). Faculty need "to help students engage in higher level thinking, work together, write clearly, and present orally in a competent manner" (Wallace, 1995, p. 459). This has resulted in a growing acceptance that (a) knowledge is discovered, built, transformed, and extended by students, (b) students actively build their own knowledge, (c) faculty should help students develop their competencies and talents, and (d) meaningful education requires faculty-student and student-student interaction as they work together (Johnson, Johnson, Smith, 1991b). However, implementing effective ways to nurture student potential and skills is often difficult.

Cooperative learning is one way to actualize this new paradigm of college teaching within a supportive environment. "Carefully structured cooperative learning ensures that students are cognitively, physically, emotionally, and psychologically actively involved in constructing their own knowledge and is an important step in changing the passive and impersonal character of many college classrooms" (Johnson, Johnson, and Smith, 1991a, pp. 1:12-13). Obler, Arnold, Sigala, and Umbdenstock (1991) assert that cooperative learning is an especially effective instructional method for the community college student.

\section{Cooperative learning}

\section{Description of cooperative learning.}

Cooperative learning is the instructional use of small groups so that students work together to maximize their own and each other's learning (Johnson, Johnson, and Holubec, 1994a). It is a "group learning process built on the belief that students learn better when they learn together" (Natasi and 
Clements, 1991, p. 110). The group is small enough that everyone can participate in a collective task that has been clearly assigned without the direct and immediate supervision of the teacher (Cohen, 1994a). Slavin (1990) describes the small cooperative group as an instructional environment in which individual and group rewards are used to encourage student participation in tasks structured to increase helping behaviors by its' members. Cooperative learning methods can be used to structure classroom situations that facilitate collaborative efforts among students to achieve academic and social goals (Goodsell, Maher, Tinto, Smith, and MacGregor, 1992; Tobin, Tippins, and Gallard, 1994). "Cooperative learning is indicated whenever (a) learning goals, content mastery, and retention are important; (b) the task is complex or conceptual; (c) divergent thinking or creativity is desired; (d) problem solving is desired; (e) high quality of performance is expected; and (f) higher level reasoning strategies and critical thinking are needed" (Johnson, Johnson, and Smith, 1991a, pp. 2:13-4).

\section{Learning Together model.}

The Learning Together model is a cooperative learning model that evolved from the work of Kurt Lewin, Morton Deutsch and David and Roger Johnson. Lewin believed that interdependence among members was the essence of groups. Deutsch differentiated between (a) a cooperative goal structure which links individual goals together, (b) a competitive goal structure which achieves individual goals by blocking others from success and (c) an individual goal structure which enables a student to achieve a goal without affecting or being 
affected by the achievement of other students (Maruyama,1991). David and Roger Johnson evolved a combination of the Lewin and Deutsch theories which assumes that if students' learning goals are structured cooperatively, then the students will help, encourage, and support each other's effort to achieve. During the past 25 years David and Roger Johnson have researched the use of a cooperative learning classroom versus a competitive or individualistic classroom. They found that this instructional approach results in (a) increased task involvement, (b) increased exchange of expertise which maximized student learning, (c) enhanced perspective-taking accuracy, (d) insight into discussion issues and synthesis of many perspectives occurred more often, (e) higher quality decisions and solutions to complex problems for which divergent viewpoints could plausibly be developed, $(f)$ enhanced ability to generalize the concepts learned to a wider variety of situations, ( $g$ ) greater student mastery and retention of the subject matter, (h) more positive relationships among participants, (i) greater sense of peer academic support, and (j) higher academic self-esteem (Johnson, Johnson, and Smith, 1991a).

The five basic elements of the Learning Together model are (a) positive interdependence, (b) face-to-face interaction, (c) individual accountability, (d) social skills, and (e) group processing. Four or five member heterogeneous teams are used (Johnson, Johnson, and Smith, 1991b).

\section{Student Team-Achievement Divisions (STAD) model.}

The STAD technique was developed by Robert Slavin. His research during the past 21 years has focused on the use of cooperative learning 
among elementary and secondary students. His findings led him to the conclusion that cooperative learning methods can be an effective means of increasing student achievement only when group goals and individual accountability are incorporated (Slavin, 1990).

The STAD model includes teacher assignment of students to learning teams and five fundamental components which comprise the foundation of this cooperative learning method. They are (a) class presentations by a teacher, (b) heterogeneous teams of four or five members working together to help each other master the information, (c) individually taken quizzes, (d) individual improvement scores where students can earn points for their team based on exceeding past quiz performance, and (e) team recognition by a newsletter, special privileges, or rewards (Slavin, 1991a). Team scores are also used to motivate student learning.

\section{Types of cooperative learning groups.}

Cooperative learning can be designed in a variety of ways. These strategies can be implemented in formal, informal, or base groups (Johnson, Johnson, and Smith, 1991b).

Formal groups have a fixed membership, last from a class period to several weeks, and have a well-defined task to accomplish. They may be structured to help students learn information, master concepts, or solve problems.

Informal groups are temporary and ad hoc. They last only for a discussion or one class period. Their purpose is to (a) create an atmosphere for learning, 
(b) help organize lecture material in advance, (c) focus student attention on the material to be learned, (d) ensure active cognitive processing of the material being taught, and/or (e) provide closure to the instructional session.

Base groups are long-term, stable, mixed ability teams. They provide peer support, encouragement, and assistance for academic achievement (Nattiv, Winttzky, and Drickey, 1991). Students can ask questions in the relative safety of a small peer group. The quantity and quality of learning is significantly improved when base groups are used. "The larger the class or college and the more complex and difficult the subject matter, the more important base groups are" (Johnson, Johnson, and Smith, 1991b, p. 10). Caring and committed relationships which are crucial to a successful college experience can develop. Cooperative learning and higher education

During the past decade cooperative learning has extended from the elementary and secondary level to higher education. It is effective in higher education because (a) it actively involves students in the learning process, (b) enables monitoring of students' comprehension, (c ) establishes a modelpractice-feedback loop, (d) implements principles of human information processing and memory, (e) creates multiple opportunities for peer-learning and peer-teaching, (f) implements principles of human motivation, $(g)$ supports interdependent, self-directed learning, (h) involves principles which promote student retention, and (i) incorporates various learning styles and multiple intelligence levels (Cook, 1991; Cooper, 1992; Cooper and Mueck, 1990; Courtney, Courtney, and Nicholson, 1994; Cuseo, 1992; Johnson, Johnson, and 
Smith, 1991a,b; Millis, 1990; Slavin, 1993). Cooperative learning is a structured and systematic instruction tool which can help students connect their personal preconceptions and evolve them into accurate science knowledge. It provides a practical framework to bridge the gulf between instructor and student and create a sense of community (Whipple, 1987).

Benefits of effective cooperative learning in higher education.

The gains in elementary and secondary education when cooperative learning is used may be also seen in higher education. Research has documented significant improvements in the areas of achievement, cognitive growth and thinking, attitudes, motivation, inter-group relations, self-esteem, and retention when cooperative learning strategies are included.

Bykerk-Kauffman (1995) began including cooperative learning activities into her university geology classes because (a) today's students need more interactive learning modes, (b) when students construct their own knowledge it is more meaningful, and $(c)$ traditional higher education instruction strategies are not effective for many students.

Cooperative learning enhances student (a) motivation by fostering active participation, (b) practice by providing opportunities for peer modeling, (c) retention by enabling cognitive rehearsal to occur, (d) transfer because small group tasks facilitate transfer of ideas from one setting to another,

(e) accommodation of various learning styles, ( $f$ ) exposure to different perspectives, and $(\mathrm{g})$ higher order thinking, analysis, synthesis, and evaluation (Davidson and O'Leary, 1990). 
Natasi and Clements (1991) in their review of the cooperative learning research literature concluded that this method "can enhance academic achievement and cognitive growth, motivation and positive attitudes toward learning, social competence, and interpersonal relations" (p. 111). These benefits have been documented in such diverse subject areas as business, chemistry, engineering, literature, psychology, and physics. Cook (1991) stated in her evaluation of cooperative learning that it seems to "be effective in raising the level of university student achievement and attitude" (p. 27).

Cooperative learning in colleges and universities

Achievement in colleges and universities.

Johnson, Johnson, and Smith (1990) concluded that college students must be actively involved in the learning process if they are to maximize their academic achievement. Classrooms which include cooperative learning require that students must (a) explain what they are learning to each other, (b) discover each other's viewpoint, (c) give and receive classmate support, and (d) delve beyond a superficial understanding of the concepts being taught. Cooperative learning can help students (a) set a productive learning mood, (b) focus on academic content, (c) engage intellectually in the material being taught, (d) identify misconceptions and gaps in understanding so that they can be corrected, and (e) increase concept retention and transfer by discussion and elaboration (Johnson, Johnson, and Smith, 1990). Students who learn cooperatively get higher grades than students who try to learn the material individually (Johnson, Johnson, and Smith, 1991b). 
Bykerk-Kaufman (1995) discussed her experience using the Jigsaw technique at California State University, Chico $(n=161)$. Increased achievement was more significant in the structural geology than the general geology course. She attributed this difference to the greater motivation of the science majors in structural geology and the possibility that the non-science majors in general geology may not have been cognitively ready for the Jigsaw approach. Inclusion of small group work in the general geology laboratory resulted in students working harder, greater persistence in problem solving, and higher achievement on exams.

George (1994) evaluated the effects of the cooperative learning strategies (a) drill and review dyads and (b) think-pair-share at North Carolina Central University. Students in the experimental sections $(n=61)$ of the education psychology course at this multicultural university achieved significantly higher total test and final exam scores.

Hufford's concern for the historically poor performance of AfricanAmerican students at George Washington University led him to consider cooperative learning in the introductory biology lecture and laboratory course. Laboratory exercises were redesigned to require small group experiments. Students ( $n=a p r o x i m a t e l y 300$ ) achieved significantly higher grades than previous students who had not participated in cooperative learning (Hufford, 1991).

Klionsky (1998) examined the use of cooperative learning in an introductory biology course at the University of California, Davis. During the lac 
operon segment students were assigned seating, organized into groups of four to five, given a group problem to discuss and solve in class, and administered individual quizzes. Eighty six percent ( $n=a p p r o x i m a t e l y ~ 300)$ of the students reported that this strategy helped them learn the material. They felt more comfortable asking questions in the smaller groups. The quiz and final exam results indicated that concept mastery was greater when cooperative learning was used.

Smith, Hinckley, and Volt (1991) incorporated the Jigsaw technique into a section of the introductory chemistry course at Southern Illinois University. Students in the experimental section $(n=21)$ achieved higher grades on the laboratory exams than the control section $(n=31)$.

Trautwein, Racke, and Hillman (1997) investigated the use of cooperative learning at Southwest Missouri State University. Students in the experimental sections $(n=309)$ of the anatomy and physiology laboratory course had significantly higher scores than those in the traditional sections $(n=497)$.

\section{Attitude in colleges and universities.}

Cooperative learning promotes a better learning environment. Students develop more positive attitudes toward the instructional experience and the instructors (Johnson, Johnson, and Smith, 1991b).

Cooper (1995) found that students who had participated in the cooperative learning sections of the chemistry laboratory course at Clemson University had more positive attitudes toward science and the laboratory. She surmised that the 
opportunity to work in small groups helped students feel more comfortable in the chemistry laboratory.

Cooper and Mueck (1990) evaluated cooperative learning in several courses (e.g. biology, French, sociolinguistics, statistical methods, and educational research methods) at California State University, Dominquez Hills. A student survey $(n=1,038)$ indicated that they believed that cooperative learning was more effective than traditional (competitive and/or individualistic college instruction). Students felt an improvement in their (a) academic achievement, (b) higher level thinking skills, (c) interest in subject matter, (d) time on task, (e) ability to evaluate their subject mastery, (f) frequency and quality of classmate interactions, $(\mathrm{g})$ class morale, and $(\mathrm{h})$ rapport with the instructor.

Courtney, Courtney, and Nicholson (1994) researched the implementation of cooperative learning into a graduate statistics course at Eastern Kentucky University. Ninety two percent $(n=32)$ of the students in the experimental section reported (a) enhanced motivation, (b) reduced anxiety, and (c) greater social cohesiveness.

George (1994) investigated cooperative learning in an undergraduate educational psychology course at North Carolina Central University. Students $(n=61)$ at this predominantly African-American state university reported significantly more favorable attitudes toward classroom instruction. 


\section{Cooperative learning in community colleges}

\section{Achievement in community colleges.}

Basili and Sanford (1991) researched the use of small cooperative groups in a general chemistry course at Prince George's Community College. Concept maps were used in the experimental sections to identify misconceptions and stimulate discussion. Students $(n=32)$ who had participated in cooperative learning had significantly less misconceptions on four of the five target concepts than students in the control sections $(n=27)$. Their concept mastery was greater. Heller and Hollabaugh (1992) analyzed the value of mixed ability and gender grouping at Normandale Community College. Cooperative problemsolving groups became a feature of the physics course. An opportunity to explain or elaborate a concept positively affected the academic achievement of high and low ability students. Rotating roles and group processing were found to be essential in building productive groups. Groups composed of students with different ability levels were significantly more able to problem solve than any individual in the group on matched problems. The individual problem solving ability improved over time at approximately the same rate for high, medium, and low ability students.

Temperly (1994) explored the use of the Jigsaw II strategy at Delta College. The achievement of students in the cooperative learning anatomy and physiology laboratory course at this community college was significantly greater. Ninety percent $(n=39)$ of the students achieved a $C$ or higher on the practical exam. 
Attitude in community colleges.

Support from caring peers are important as community college students develop attitudes which value education and hard work in school. This can be an especially helpful tool for science-anxious community college students (Caprio, 1993).

Essential components of cooperative learning in higher education Implementation of cooperative learning involves more than putting students in groups. Groups must be carefully structured and implemented.

The exploration of effective cooperative learning in higher education has identified several essential elements. These include (a) positive interdependence among group members, (b) individual accountability, (c) a rationale for grouping, (d) structured student interaction, (e) instructor monitoring and facilitation, and (f) explicit attention to social skills and group processing (Bruening, 1990; Cook, 1991; Cooper, 1992; Cooper and Mueck, 1990; Cuseo, 1993; Johnson, Johnson and Smith, 1991a,b; Millis, 1990).

\section{Rationale for grouping.}

Faculty must think carefully about why and how cooperative learning should be implemented in their college courses (Cooper, 1990; Cooper, 1995; Rau and Heyl, 1990; Vermette and Erickson, 1996). As a radical departure from the usual competitive and/or individualistic higher education methods the instructor must explain explicitly to students the rationale for requiring this technique. 
Appropriate instructor assignment of students to groups is pivotal in the eventual success or failure of that group (Cooper and Mueck, 1990). A survey of undergraduates involved in small group learning $(n=215)$ at Texas $A$ \& M and the University of Oklahoma concluded that students are more likely to have positive experiences in classes where groups are formed by the instructor (Feichtner and Davis, 1984-5).

Higher education research suggests that heterogenous, four or five person, base groups seem to be the most effective in producing operational groups. These groups reflect a diversity of ability, ethnicity, and gender. Smaller groups lack resources and larger groups have difficulty maintaining cohesiveness. Higher-level skills in group problem solving can be developed by placing students in mixed ability groups and giving them multiple opportunities to make decisions and receive feedback on their performance (Feichtner and Davis, 1984-5). Low and middle achieving students can see higher achieving students in action as they analyze, evaluate, and synthesize information. High achieving students benefit from the opportunity to elaborate which increases their content mastery. All these elements result in deeper understanding, better quality of reasoning, and more accurate long-term retention (Johnson, Johnson, and Smith, 1991b),

\section{Structured student interaction.}

The instructor must design an environment that develops, facilitates, and monitors cooperative learning (Cook, 1991; Courtney, Courtney, and Nicholson, 1994; Purdom and Kromrey, 1995). A "deeper awareness of small group 
processes can enhance teaching effectiveness of college faculty through improving their ability to raise student participation levels, increase individual and group motivation, stimulate enthusiasm, and facilitate communication in the classroom" (Billson, 1986, p. 143). Community college students are encouraged to become more responsible for making sense of science concepts when small group tasks are carefully structured (Basili and Sanford, 1991).

\section{Positive interdependence.}

Fundamental to small group interaction is the belief that each group member is ultimately responsible for the group's effectiveness. Each student must accept that individual success is dependent on the success of all the group members. This requires that everyone encourages and facilitates each other's effort to achieve, complete tasks, and produce in order to reach the group's goals (Johnson, Johnson, and Smith, 1991a).

Positive interdependence can be established through mutual learning goals, joint rewards, shared resources, and complementary roles (Fleming, 1995; Hufford, 1991; Smith and Hinckley, 1991). Mutual learning goals would be ensuring that all group members master the course material and achieve a final grade of B or more. Joint rewards can be based on the individual achievement of each group member. Bonus points can be awarded to groups in which all members achieve an established achievement level (Bruening, 1990). It is a way to make sure that able students take the trouble to help their teammates really learn and not just complete their group assignment. Sharing resources among group members compels individuals to interact while 
accomplishing academic tasks (Johnson, Johnson, and Stanne, 1989).

Complementary roles are different task structures that require interdependent roles for students (Cohen, 1994b). Keeping the group size small and rotating roles gives everyone a chance to practice important academic skills within a supportive environment before attempting them on their own.

Deavor (1994) described the value of rotating student roles and teamwork in an experimental section $(n=20)$ of the quantitative analysis laboratory course at the College of Charleston. Students became responsible for accomplishing all experiment goals. The professor functioned as a consultant. All problems were directed to the team manager for resolution. Students felt that this cooperative learning approach enhanced their problem-solving, organizational, and team member skills.

Individual accountability.

Interdependent roles such as experiment leader, expert, curator, and reporter requires students to fulfill their individual responsibilities if the group is to complete their assignment successfully. The use of specific roles minimizes the risk of the "free rider" and the "rich get richer" phenomenon (Johnson, Johnson, and Smith, 1991b). It is more difficult for students to decrease their efforts and rely on the productivity of other group members to complete tasks or for high ability students to take over leadership roles which benefit themselves at the expense of other group members.

Individual students must demonstrate their mastery of the assigned work (Bykerk-Kaufman, 1995). This can be accomplished by individual quizzes or oral 
summaries. "In science, laboratory reports may be turned in by the team, but each week a randomly drawn member must do the oral explanation of their session" (Vermette and Erickson, 1996, p. 208). Evaluating the contribution of each student to group tasks helps identify those students who need assistance, encouragement, and/or support.

Explicit attention to social skills and group processing.

Placing students in a group and telling them to work together does not produce cooperation. Successful cooperative learning requires interpersonal and small group skills (Cooper, 1992). They are key to group productivity (Johnson and Johnson, 1997).

Even college students need skills training prior to cooperative learning (Cook, 1991). They must be taught those social skills necessary for group effectiveness. These include (a) team building, (b) face to face verbal problem solving, (c) task support, (d) social support, and (e) group processing and evaluation (Hertz-Lazarowitz and Miller, 1992). This means training students to share ideas and information, modify and use different viewpoints, keep the group on task, compliment and encourage the participation of others, and check to ensure that all group members understand what was taught. Mastery of these social skills will help students (a) get to know and trust one another, (b) feel comfortable participating, (c) communicate accurately and unambiguously, (d) accept and support one another, and (e) resolve conflicts constructively. The instructor can "specify the group skills to use, observe the groups in action, and then provide feedback in a large-group setting, noting how well the 
group members are using the skills" (Johnson, Johnson, Stanne, and Garibladi, 1989, p. 509). The more attention an instructor spends in teaching and rewarding the use of social skills the greater the achievement will be in cooperative learning groups (Johnson, Johnson, and Smith, 1991a).

Students must evaluate group sessions to identify and describe the member actions that were helpful and to decide what actions to continue or change. The intent of group processing is to clarify and improve the effectiveness of each member in contributing to the attainment of the group's goals (Johnson, Johnson, and Smith, 1991a,b). Students need to analyze and discuss how well the group is (a) accomplishing their tasks and (b) working together to improve the group's interaction and effectiveness (Vermette and Erickson, 1996). Time should be provided for positive group interaction, encouraging social skills use, and reinforcing the importance of group processing (Johnson and Johnson, 1992). These elements are very influential in maximizing group productivity and individual achievement.

\section{Instructor monitoring and facilitation.}

The instructor must monitor groups, intervene to teach appropriate behaviors, and provide time for students to process their interactions on instructional tasks (Cuseo, 1993). These steps are crucial to the success of any cooperative learning venture.

Tewksbury (1995) investigated the impact of the Jigsaw technique in geology courses at Hamilton College. She concluded it was important that the instructor (a) checked on each group at least once during a discussion to see if 
they are on the right track, (b) sit in on group sessions periodically, (c) evaluate each person's ability to teach the rest of the group, and (d) provide feedback as soon as possible.

Faculty can provide the best feedback about what students should know. Students should be given time to work out group problems (Nuffield Foundation, 1977b). Only when a group becomes dysfunctional should an instructor step in to help students analyze the problem and develop potential solutions. "Sensitivity to group-building and maintenance techniques will contribute to enhanced student satisfaction, success, and retention by raising levels of both academic and social involvement in the learning process" (Billson, 1986, p.150). Cooperative learning in the higher education science laboratory

The science laboratory is a place where students can work cooperatively as they develop their investigative and cognitive skills to examine scientific phenomena (Lawson, 1992). "Laboratory activities... can promote positive attitudes, and they provide opportunities for student success and foster the development of skills in cooperation and communication " (Hofstein and Lunetta, 1982, p. 212).

Constructing an optimal small group environment in the science laboratory can promote students' sharing ideas, questioning each other, understanding, and problem-solving. "Laboratories... provide unique opportunities in science teaching to engage students in cooperative, small-group interaction that can facilitate learning" (Lunetta and Hofstein, 1991, p. 136). 
Cooperative learning in higher education science laboratories has been researched in (a) anatomy and physiology (Temperly, 1994; Trautwein, Racke, and Hillman, 1997), (b) biology (Hufford, 1991; Leonard, 1991), (c) biochemistry (Stefani and Tariq 1996), (d) chemistry (Basili and Sanford, 1991; Bier, 1993; Cooper, 1993, 1994; Deavor, 1994; Fleming, 1995; Kandel, 1994; Martin, 1995; Smith and Hinckley, 1991; Varco-Shea, Darlington, and Tumbull, 1996), and (e) geology (Bykerk-Kaufman, 1995). Results to date indicate that cooperative learning may have a beneficial effect on attitudes and achievement in the higher education science laboratory.

The impact of redesigning a non-science majors' general biology laboratory course at a community college on students' attitudes toward science and/or achievement is not well documented. A literature search yielded 109 articles about science in higher education. Only two studies investigated the effect of curricular changes in an introductory biology laboratory course at a community college (Haukoos and Penick, 1983; Mills, 1981). However, both these studies were limited to the positive effect of incorporating investigation and discovery techniques on academic achievement.

Science-related attitudes

Attitudes that are linked to science are usually separated into the two major categories of scientific attitudes and attitudes toward science (Schibeci, 1984). There is a distinction between having scientific attitudes and being willing to implement them. Attitudes toward science refers to the adoption of scientific attitudes. More education researchers have become interested in attitudes 
toward science. This increased focus is based on the two assumptions (a) that attitudes toward science may be more important than a student's understanding of science since attitudes determine how well that student will use their science knowledge and (b) although a student has the ability to do science tasks, their willingness to do these tasks originates in the affective domain (Okebukola, 1986).

Scientific attitude.

Although the terms scientific attitude and attitudes toward science are often used interchangeably they are distinctly separate terms. Scientific attitude refers to those attributes that a scientist would use in accomplishing professional work (Schibeci, 1984). The perception of a scientist's professional characteristics includes open mindedness, honesty, skepticism (Gardner, 1975), curiosity, humility, creativity, critical-mindedness, objectivity, a willingness to suspend judgement until all the evidence is weighed (Gauld and Hukins, 1980), and rationality (Haney, 1964).

\section{Attitudes toward science.}

Attitudes toward science refers to "a general and enduring positive or negative feeling about science" (Koballa, Jr. and Crawley, 1985, p. 223). These attitudes toward science are important because they are believed to influence future behaviors. Attitudes toward science is often used as an umbrella term (Munby, 1980). This term may include interest, enjoyment, or satisfaction in science, attitudes toward scientists (Gardner, 1975), attitudes to science itself, 
attitudes to science instruction, attitudes to science careers, or attitudes to specific science issues (Munby, 1980).

Instruments for measuring attitudes toward science.

Bollen (1972) discussed key elements in developing an effective attitude instrument. His research led him to several conclusions (a) that the Likert scale was the most appropriate attitude scale and (b) that attitude statements should be interesting, meaningful, form a logical sequence, use language that the respondent can easily comprehend, clearly describe the situation on which the respondent is asked to express an opinion, and include statements which express the opposite sentiments from those of the authors in order to avoid a set response.

The researcher must take great care in determining if an instrument is measuring attitudes toward science or scientific attitudes. An example is Moore's Scientific Attitude Inventory (SAI). The title is misleading because it does not measure scientific attitudes but rather a respondent's attitude towards or beliefs about science (Gauld and Hukins, 1980). Munby (1980) described his conceptual analysis of the SAI, the most popular attitudes toward science instrument. After evaluating its' use in 30 studies he concluded that " we can be less than certain of what is measured by the SAl" (Munby, 1983, p. 141). The conceptual analysis revealed that many questions in the SAI subscales did not actually measure attitudes but rather it assessed cognitive knowledge. Therefore, the conceptual validity of the SAl subscales is questionable. 
An extensive review indicated that the most appropriate, valid, and reliable attitude instrument for this study would be the TOSRA (see Appendix A.) The initial development and validation of the TOSRA was described in detail by Fraser (1978). This instrument has a clearly-defined theoretical construct. The short, reliable subscales produce separate scores which are more useful than one global score. The ten items in each scale are related to a singe attitude object. A meaningful score can be obtained since items relating to different attitudes are not grouped together. Schibeci (1984) includes Fraser's TOSRA in the number of well established methods available to the attitude researcher.

A literature search did not identify any previous studies comparable to the current study. Therefore, no similar studies could be located that used the TOSRA.

\section{Determining biology achievement}

A goal of this study was to increase the biology knowledge of the students in BSC 1005L. This required an initial and final evaluation of their biology understanding. A literature search was conducted to identify currently available cognitive biology assessment instruments. After reviewing the results, the three full-time faculty members who teach BSC 1005 and BSC $1005 \mathrm{~L}$ at the study site chose the BSC 1005 textbook test bank as their primary resource. They then selected 30 multiple-choice items from this test bank to comprise the cognitive biology test to be used in this study (see Appendix B). Items were chosen to reflect the fundamental concepts that a student is expected to have mastered upon completion of BSC 1005L. 


\section{Summary}

This chapter has provided an overview of several important aspects related to this study: (a) research on cooperative learning in higher education has shown significant gains in attitudes toward science and achievement; (b) the effect of incorporating cooperative learning into biology laboratory courses has been documented at only two universities (Hufford, 1991; Leonard, 1991), its' impact in a community college biology laboratory course has yet to be reported in the literature; (c) effective implementation of cooperative learning requires positive interdependence among group members, individual accountability, a rationale for grouping, structured student interaction, instructor monitoring and facilitation, and explicit attention to social skills and group processing; (d) a literature search identified the TOSRA as the most valid and reliable instrument to measure attitudes toward science; and (e) full-time biology faculty at the study site preferred to use the BSC 1005 textbook test bank as the resource for the cognitive biology test items to be used in this study. 
Chapter Three

Methodology

Components of the Learning Together model by David and Roger Johnson and the Student Team-Achievement Divisions model by Robert Slavin were combined. Specific cooperative learning techniques were included in the experimental sections of BSC $1005 \mathrm{~L}$ to (a) facilitate positive interdependence among group members (teams, bonus points, laboratory reports), (b) individual accountability (team contract, experiment responsibilities, weekly quiz, evaluations), (c) structured student interaction (team, station assignment, experiment role), (d) social skills and group processing (cooperative learning handouts, discussion, practice, evaluations). The impact of the cooperative learning strategies on community college students was examined. Setting

The study was conducted during the 1998 spring (January) term on the same campus of a large, culturally diverse, multicampus, urban public community college in South Florida. It is accredited by the Southern Association of Colleges and Schools, and offers the Associate of Arts transfer degree as well as the Associate of Science degree in 51 areas to prepare students for employment and four year college programs. Graduation from high school is the only entrance requirement.

All students at the institution where the study was conducted are required to fulfill a natural science requirement for graduation. BSC 1005 - general biology 
and BSC 1005L - general biology laboratory are the courses most frequently chosen. During the 1996-1997 academic year there were 2,207 students enrolled in BSC 1005L. According to K. Mascetti (personal communication, May 14,1998) only $1,484(67.24 \%)$ successfully completed the course with a grade of $C$ or higher.

Students in BSC 1005 L were selected for this study because (a) they usually well represent the heterogeneous population of this community college with respect to ability, ethnicity, and gender; (b) many students enroll in this course but do not successfully complete it (32.76\% in the $1996-1997$ academic year); (c) the course procedure and physical environment could be manipulated yet attain the course objectives; and (d) an instructor was willing to participate in the study.

\section{Instruments}

The critical measurements in this study are attitudes toward science and cognitive biology achievement. These variables were assessed by the Test of Science-Related Attitudes (TOSRA) and a biology test.

\section{Test of Science-Related Attitudes (TOSRA).}

The attitudes toward science of each student in the sample were measured by the TOSRA. A literature search did not identify any previous studies comparable to the current study. Therefore, no similar studies could be located that used the TOSRA. However, an extensive review indicated that the most appropriate, valid, and reliable attitude instrument for this study would be the TOSRA (see Appendix A). The initial development and validation of the 
TOSRA was described in detail by Fraser (1978). Permission to use the TOSRA was granted by the author, Dr. Barry J. Fraser. It is currently out of print and no Ionger available from the Australian Council for Educational Research. This instrument considers each of the distinct attitude categories identified by Klopfer (1976). It is a measure of a respondent's attitudes toward science. It can be used to monitor student progress towards achieving attitudinal goals, particularly those that are derived from laboratory experiences (Lunetta and Hofstein, 1991). It is composed of 70 statements within seven scales: (a) social implications of science, (b) normality of scientists, (c) attitude toward inquiry, (d) adoption of scientific attitudes, (e) enjoyment of science lessons, (f) leisure interest to science, and $(\mathrm{g})$ career interest in science. Each scale consists of 10 statements to which respondents are asked to determine their level of agreement. Five responses are available (strongly agree, agree, neutral, disagree, strongly disagree). A five point Likert-type scale is used. The scoring is reversed on half the items in each scale. The possible score range on each scale is from a minimum of 10 to a maximum of 50 (Fraser, 1981).

Test of Science-Related Attitudes instrument validity.

Fraser in 1978 reported the procedure for development of the final version of the TOSRA. Preliminary versions were refined in two successive steps. Step one included revising the item pool to reflect comments by science teachers and educational measurement experts regarding the clarity, readability, face validity, and scale allocation of each item (p. 511). No details were provided about the credentials or number of science teachers and educational measurement 
experts consulted. Step two field tested a TOSRA version with 14 items per scale, analyzed each item, and reduced each scale to 10 items.

During 1977 the 14 item per scale version of the TOSRA was field tested in the Sydney, metropolitan area. The sample consisted of 1,337 students in grades 7-10 from 11 schools. Each school provided a typical and similar class in grades $7,8,9$, and 10 . Schools were carefully chosen to reflect the broadest range of socioeconomic and geographic areas in this Australian school population. There were equal numbers of male and female students at each grade level. The mean score on each scale tended to be approximately the same at all grade levels. The standard deviation for a given TOSRA scale was also comparable at each grade level.

Discriminant validity (the extent to which a given scale measures a unique attitude not measured by another scale in the series) was evaluated by calculating the intercorrelations among the seven TOSRA scales. The mean correlation of a TOSRA scale with the other six scales in 1977 ranged from 0.13 to 0.40 , in 1979 ranged from 0.23 to 0.42 (United States data), and in 1981 ranged from 0.23 to 0.43 . These values indicate moderately low mean correlations of a given scale with the other six scales.

The TOSRA was field tested in Australia in $1977(n=1,377)$, in the United States in $1979(n=546)$, and in Australia in $1981(n=712)$. The comparable values of the scale statistics obtained from the Australian and the American samples support the cross-cultural validity of the TOSRA for use in the United States. 


\section{Test of Science-Related Attitudes instrument reliability.}

The internal consistency was estimated for each scale using the Cronbach $\alpha$ coefficient. The values of the reliability $\alpha$ coefficient in 1977 ranged from 0.67 to 0.92 with a mean of 0.82 , in 1979 ranged from 0.63 to 0.92 with a mean of 0.79 (United States data), and in 1981 from 0.62 to 0.91 with a mean of 0.80 . These reliability coefficient values are generally high for scales whose length is only ten items. All values were large enough to indicate that each TOSRA scale had good internal consistency reliability at each grade level.

A subsample of students $(n=238)$ in the 1977 study were given the TOSRA two weeks after the first administration. The test-retest coefficients ranged from 0.69 to 0.84 with a mean of 0.78 , thus indicating that all TOSRA scales displayed quite good test-retest reliability.

\section{Cognitive biology test.}

A cognitive biology test was used to assess the individual biology knowledge of each student in the sample. The 30 -item, multiple-choice cognitive biology test was constructed by three full-time faculty members who teach BSC 1005 and BSC $1005 \mathrm{~L}$ at this urban community college (see Appendix B). Test items were selected from the test bank of the BSC 1005 textbook required at the campus where the study was conducted. Items were chosen to reflect the fundamental concepts that a student is expected to have mastered upon completion of BSC 1005L. 
Achievement in BSC $1005 \mathrm{~L}$ was measured by a review of the pre and post cognitive biology test scores of each student in the experimental and control groups. The possible score ranged from a minimum of 0 to a maximum of 30 . Subjects

The sample attended BSC 1005 for two and a half hours and BSC 1005L for two hours each week over a 16 week term. All sections of BSC 1005 used the same textbook. Concepts developed in the lecture (BSC 1005) and the laboratory (BSC 1005L) course were coordinated. It was expected that acquisition of some knowledge and skills from the lecture course would contribute to performance in the laboratory course.

The experimental and the control groups each consisted of two sections of BSC $1005 L\left(n_{1}=27, n_{2}=19\right)$. Anonymity of the study participants was maintained by assigning each student a three digit code for identification on the TOSRA and the cognitive biology test.

Limited demographic data was available from each student (see Appendix C). The study population was summarized and analyzed for ability, ethnic, and gender composition. An analysis of the sample revealed a student composition of (a) $45.7 \%$ male, $54.3 \%$ female and (b) $60.9 \%$ White non-Hispanic, 8.7\% Black non-Hispanic, $19.6 \%$ Hispanic, and 8.7\% Asian/Pacific Islander. There were no native Americans, unknown, or non-resident aliens identified. This differs slightly from the most recent (1995 fall term) national profile of community college students (Phillippe, 1997). This survey found that the population attending American community colleges were (a) $41.8 \%$ male, $58.2 \%$ female and 
(b) $67.3 \%$ White non-Hispanic, $10.9 \%$ Black non-Hispanic, $10.6 \%$ Hispanic, $5.5 \%$ Asian/Pacific Islander, 1.3\% American Indian, 3\% unknown, and 1.5\% nonresident alien.

Statistical procedure and analyses

Data collection.

Demographic data were collected from students in the experimental and control groups at the beginning of the term. Students in the cooperative learning group $\left(n_{1}=27\right)$ were administered the TOSRA and the cognitive biology test at the same time as the control group $\left(n_{2}=19\right)$ (at the beginning and end of the term).

\section{Statistical analyses.}

Chi square tests were chosen to analyze the categorical data (e.g. ethnicity, gender). I-tests were used to compare the interval scale numerical data (e.g. college grade point average, absences during the study, pretest/ posttest mean scores of the cognitive biology test and the TOSRA, mean score differences of the cognitive biology test and the TOSRA).

Due to the number of absences during the term, only those students with both the pretest and posttest scores of the TOSRA and the cognitive biology test were included in the statistical comparisons $\left(n_{1}=27, n_{2}=19\right)$. Chi-square and t-test analyses were performed to determine the equivalence of the experimental and control groups regarding ethnicity, gender, college grade point average, and number of absences. I-tests on the differences, independent samples and paired samples t-tests were performed using the mean scores of the experimental and control groups on the two administrations of the TOSRA and the cognitive 
biology test. Analysis of Covariances were performed using the adjusted post mean scores of the TOSRA and the cognitive biology test of the experimental and control groups. All statistical tests were performed at $\alpha=.05$.

\section{Design}

A quasi-experimental pretest-posttest control group design was used to measure the effect of cooperative learning strategies, if any, on students' attitudes toward science and cognitive biology achievement. Since it was not possible to randomly select or assign students to experimental and control groups, a true experiment could not be performed. However, to help establish equivalence of the experimental and control groups the design utilized the same BSC $1005 \mathrm{~L}$ (a) instructor, (b) laboratory, (c) laboratory manual, (d) laboratory experiments and equipment, (e) laboratory quizzes, (f) biology films and videos, and $(\mathrm{g})$ computer simulations. Two intact sections of BSC $1005 \mathrm{~L}$ were randomly selected to be the experimental group. The remaining two sections of BSC $1005 \mathrm{~L}$ which were taught by the same instructor comprised the control group.

\section{BSC 1005L cooperative learning sections.}

The cooperative learning strategies were selected by reviewing science education, cooperative learning, small group development, science laboratory, and attitude theoretical and research resources. It was determined that the most appropriate cooperative learning techniques for BSC $1005 \mathrm{~L}$ would be a combination of various components of (a) the Learning Together model developed by David and Roger Johnson and (b) the Student Team-Achievement Divisions model created by Robert Slavin. This composite cooperative learning 
approach utilized elements of the Learning Together model: (a) positive interdependence among group members, (b) face-to-face interaction, (c) individual accountability, (d) social skills, (e) group processing, and (f) base groups and the Student Team-Achievement Divisions model: (a) appropriate assignment of students to learning teams, (b) class presentations by an instructor, (c) heterogeneous teams of four or five members working together to help each other master the information, and (d) individually taken quizzes. The cooperative learning laboratory design included (a) team building, (b) structured student interaction, (c) instructor monitoring and facilitation, and (d) explicit attention to social skills and group processing. Techniques such as teams, a team contract, laboratory station assignment, experiment roles, laboratory reports, evaluations, weekly quiz, bonus points, cooperative learning handouts, discussion, and practice were planned into the experimental sections of BSC 1005L.

\section{Instructor.}

All sections were taught by the same full-time instructor. Her credentials include a Ph.D. in Biological Science and more than eight years experience teaching BSC 1005 and BSC $1005 \mathrm{~L}$ at this community college. She had no prior experience using cooperative learning as an instructional method.

The instructor's role was to (a) administer the research assessment instruments (demographic, attitudes to science, cognitive biology test), (b) discuss cooperative learning strategies with students, (c) utilize team building exercises, (d) monitor experiment activities, (e) model problem-solving skills, 
(f) act as a group consultant (e.g. clarify instructions and experiment procedures),

(g) provide feedback regarding individual and group biology mastery, and

(h) facilitate lab wrap-up (e.g. group discussion of performance, individual oral summary of a group's experiment, interpret different experiment results).

\section{Researcher.}

The researcher's role was to (a) provide cooperative learning training to the instructor, (b) provide appropriate handouts (see Appendix D), (c) summarize and analyze the results of the research assessment instruments (demographic, attitudes to science, cognitive biology test), (d) evaluate and assign students to heterogeneous groups, (e) assign students to laboratory areas and initial experiment roles, (f) monitor group progress, $(g)$ review laboratory reports, individual/group performance evaluations, and (h) analyze the pre and post TOSRA and cognitive biology test results of students in the experimental and control sections of BSC 1005L. 


\section{Students.}

Student groups were responsible for determining (a) expectations, (b) how to handle absences, (c) experiment role rotation schedule, (d) experiment implementation task assignments, (e) group name, and (f) the laboratory report group meeting timetable. Agreement to these conditions was documented by each student signing a group contract .

Each group member assumed a role (experiment leader, expert, curator, or reporter) for three consecutive lab sessions. The experiment leader was to ensure (a) timely completion of experiments, (b) that each group member was doing their job, (c) that the group was working well together, (d) that all group members collaborated on the laboratory report, and (e) that group and individual performance evaluations were completed. The experiment leader was responsible for keeping the group on task, facilitating group collaboration, discussion, and decision-making. The experiment expert was to check that the group (a) comprehended relevant biology principles, (b) understood all experiment procedures, (c) could connect principles to procedures, and (d) could link principles to experiment results. This person was also responsible for making sure that all experiment steps and objectives had been achieved. The experiment curator was to ensure (a) group acquisition and distribution of handouts, equipment, and supplies, (b) group clean-up and return of equipment and supplies, (c) visits to other groups to gain feedback or additional information, and laboratory report development. This person also needed to check that all group members left with a complete understanding of the experiments performed 
during that laboratory session and accurate information. The experiment reporter was responsible for (a) recording data and maintaining the laboratory report file, (b) ensuring group discussion of the experiment results and significance, and (c) making sure that all group members verified agreement with the laboratory report by signing the original document. This person was to also write and submit the laboratory report to the instructor at the end of each laboratory session.

\section{Student assessment.}

Assessment of individual student performance included (a) review of the individual weekly quiz results and laboratory points earned, (b) review of individual performance evaluations (see Appendix E), (c) researcher observation, and the (d) results of the pre and post TOSRA and cognitive biology test.

Group assessment was to include (a) review of weekly quiz results (if all group members achieved $\geq 90 \%$ on a quiz, a $10 \%$ bonus was added to each group member's laboratory quiz grade), (b) evaluation of experiment oral summaries and written laboratory reports, (c) review of group performance evaluations (see Appendix F), and (d) researcher observation.

BSC 1005L experimental sections.

The cooperative learning general biology laboratory sections attempted to (a) aintegrate team building, (b) structure student interaction, (c) instructor monitoring and facilitation, and (d) explicit attention to social skills and group processing into the BSC $1005 \mathrm{~L}$ format during the 1998 spring (January) term.

Week one: After the assessment instruments (demographic, TOSRA, cognitive biology test) were administered the instructor explained how this 
laboratory section would be different from the traditional BSC $1005 \mathrm{~L}$ sections.

The rationale for using an alternate instructional method was discussed.

Students were given the option of transferring to the traditionally taught BSC $1005 \mathrm{~L}$ sections. No student chose to transfer to another BSC 1005 L section.

Week two: A more detailed discussion of cooperative learning was provided. Specific techniques that students would be required to practice and master during the term were elaborated. Students were observed by the researcher as they conducted their experiments. This was done to identify which students were (a) leaders, (b) shy, (c) had difficulty interacting, (d) articulate, and (e) good listeners.

Week three: Students were assigned to (a) learning teams, (b) initial experiment roles, and (c) laboratory stations. The responsibilities of each experiment role was clarified. Badges which identified each student and the team to which they belonged were distributed. Each student was requested to wear these badges during the remainder of the term to facilitate working together. As a team building exercise each student group was given the task of jointly developing a team contract. On one sheet each team was required to write the (a) telephone number of each member, (b) rotation schedule for experiment roles, (c) team expectations, (d) team policy regarding member absences and "loafing", and (e) team name. The participation and agreement of each student to this team contract was documented by their signature on the original form. Weeks four through thirteen: All written information and quizzes were returned to students in a team folder. Each week a different cooperative learning 
technique was discussed. Students were instructed to practice that strategy during that weeks' laboratory session. After the biology experiments were completed each week students were asked to complete and discuss evaluation forms (see Appendices $E$ and F).

Week fourteen: The posttest TOSRA and cognitive biology test were administered (see Table 1).

Table 1

Schedule Cooperative Learning Sections.

Week Tasks

1 Administer demographic, TOSRA, and cognitive biology test.

Discuss difference between cooperative learning and traditional BSC $1005 \mathrm{~L}$ sections and rationale for cooperative learning.

2 Discuss cooperative learning and specific cooperative learning techniques.

Researcher observation.

3 Assign students to learning teams, initial experiment roles, stations. Clarify individual experiment roles and distribute identification badges. Instruct teams to develop a contract specifying role rotation, expectations, and policies.

4-13 Distribute written information and quizzes in team folder. Instruct students to practice a specific cooperative learning technique. Instruct students to discuss personal/ team progress.

14 Administer TOSRA and cognitive biology test. 


\section{CHAPTER FOUR}

\section{Results}

The purpose of this study was to incorporate cooperative learning into the non-science majors' community college course BSC 1005L, and then to evaluate the impact of the cooperative learning strategies on community college students. The pretest and posttest performance of the cooperative learning group and the control group on a cognitive biology instrument and the Test of ScienceRelated Attitudes (TOSRA) were used to determine the effectiveness of cooperative learning strategies in positively influencing biology achievement and attitudes toward science. All statistical procedures were done at $\alpha=.05$. This chapter will present the results. The sample will be analyzed. Results from the pretest and posttest instruments will also be presented.

Analysis of the sample

Data were collected at the beginning of the study from the cooperative learning group $\left(n_{1}=27\right)$ and the control group (not cooperative learning) $\left(n_{2}=19\right)$ regarding their ethnicity, gender, and college grade point average. These variables were then analyzed to determine group equivalency before the study began.

Since categorical data were being analyzed a chi square test was selected to identify any significant differences between the cooperative learning group and the control group on the characteristics of ethnicity and gender. Due to the very low frequencies in some cells, categories were combined to reflect students belonging to the ethnic group: White-non Hispanic or other (Black, Hispanic, 
Asian/Pacific Islander, American Indian). The cooperative learning group was composed of $63 \%$ White students and $37 \%$ other ethnic group. The control group was composed of $58 \%$ White students and $42 \%$ other ethnic group. Overall, the sample was composed of $61 \%$ White students and $39 \%$ other ethnic group. No significant difference was shown in ethnic group membership by the two groups, $\underline{p}=.729$ (see Table 2). The characteristic gender was also analyzed. The cooperative learning group was composed of $52 \%$ male and $48 \%$ female students. The control group was composed of $37 \%$ male and $63 \%$ female students. Overall, there were $46 \%$ male and $54 \%$ female students in the sample. There was no significant difference in the percentage of male and female students between the two groups, $\mathrm{p}=.314$ (see Table 2).

Since grade point average and absences were represented by interval scale numerical data, t-tests were chosen as the statistical analysis procedure. The mean grade point average for students in the cooperative learning group was 2.95 versus 3.00 for students in the control group. The college grade point average of the two groups at the beginning of the term were not significantly different, $\mathrm{Q}=.786$. (see Table 2 ). The mean number of absences between the two groups during the term was not statistically significantly different, $\mathrm{p}=.150$ (see Table 2). The impact of the number of absences on cooperative learning was not significant.

To summarize, statistical analyses confirmed that the cooperative learning group and the control group were equivalent at the beginning of the study regarding ethnicity, gender, and college grade point average. Also, 
statistical analysis at the end of the study determined that the number of absences during the term between the two groups was equivalent. 
Table 2

Profile of Study Participants.

\begin{tabular}{|c|c|c|c|c|c|}
\hline Characteristic & & $n$ & $\%$ & $-x^{2}$ & $p$-value \\
\hline \multirow[t]{3}{*}{$\begin{array}{l}\text { Ethnicity } \\
\text { White }\end{array}$} & & & & 0.12 & .729 \\
\hline & Coop learning & 17 & 63 & & \\
\hline & Control & 11 & 58 & & \\
\hline \multicolumn{6}{|c|}{ Other } \\
\hline & Coop learning & 10 & 37 & & \\
\hline & Control & 8 & 42 & & \\
\hline \multirow{3}{*}{$\begin{array}{l}\text { Gender } \\
\text { Male }\end{array}$} & & & & 1.01 & .314 \\
\hline & Coop learning & 14 & 52 & & \\
\hline & Control & 7 & 37 & & \\
\hline \multicolumn{6}{|c|}{ Female } \\
\hline & Coop learning & 13 & 48 & & \\
\hline & Control & 12 & 63 & & \\
\hline \multicolumn{2}{|l|}{ Variable } & Mean & SD & $t$ & $\mathrm{p}$-value \\
\hline \multicolumn{2}{|l|}{ Absences } & & & 1.48 & .150 \\
\hline \multirow{2}{*}{\multicolumn{2}{|c|}{$\begin{array}{l}\text { Coop learning } \\
\text { Control }\end{array}$}} & .81 & .79 & & \\
\hline & & 1.26 & 1.15 & & \\
\hline \multicolumn{2}{|c|}{ Grade Point Average ${ }^{a}$} & & & 0.27 & .786 \\
\hline \multicolumn{2}{|c|}{ Coop learning } & 2.95 & .50 & & \\
\hline \multicolumn{2}{|c|}{ Control } & 3.00 & .82 & & \\
\hline
\end{tabular}

${ }^{\text {a }}$ Maximum college grade point average $=4.00$. 
Analysis of the research data

The cognitive biology test and the TOSRA were administered at the beginning and at the end of the study simultaneously to the cooperative learning group and the control group. This was done in order to address the research questions regarding the effect of the cooperative learning strategies on attitudes toward science and biology achievement. I-tests were chosen as the statistical analysis procedure since the biology and TOSRA scores were represented by interval scale numerical data.

There was no significant difference between the two groups on the pretest cognitive biology test, $\mathrm{p}=.600$. The mean pretest cognitive biology score was 10.41 for students in the cooperative learning group versus 10.00 for students in the control group (see Table 3). It is interesting to note that students in the sample were able to answer only $33 \%$ of the cognitive biology test correctly at the beginning of the study.

The TOSRA was administered to students to self-assess their attitudes toward science. The TOSRA consists of seven scales: one (social implications of science), two (normality of scientists), three (scientific inquiry), four (adoption of scientific attitudes), five (enjoyment of science lessons), six (leisure interest in science), and seven (career interest in science). The score for each scale is computed individually from ten items to reflect the respondent's attitude toward a particular segment of science. The TOSRA mean scores ranged from 32.56 to 40.16 from a possible $10-70$ points where higher scores mean more positive attitudes. Overall, the students in the sample had neutral to moderately positive 
attitudes toward science. The t-tests identified the cooperative learning group as having statistically significant lower pretest mean scores in the TOSRA scales:

one, $\mathrm{p}=.015$ (social implications of science); four, $\mathrm{p}=.017$ (adoption of scientific attitudes); five, $\underline{p}=.016$ (enjoyment of science lessons); and six, $\mathrm{p}=.015$ (leisure interest in science) (see Table 3). When the pretest TOSRA mean scores were compared between the cooperative learning and the control group there was no significant difference in the TOSRA scales: two, $\mathrm{p}=.402$; three, $\mathrm{p}=.171$; and seven, $\underline{p}=.152$. 
Table 3

Pretest Mean Scores by Group.

\begin{tabular}{cccc}
\hline & Pretest & & \\
& Mean SD & $t$ & p-value \\
\hline $\begin{array}{c}\text { Cognitive biology test } \\
\text { Coop learning }\end{array}$ & 10.412 .63 & -.53 & .600 \\
Control & 10.002 .49 & &
\end{tabular}

TOSRA subscales ${ }^{b}$

$2.54 \quad .015^{\star}$

1. Social implications of science
Coop learning
Control
36.075 .89
40.003 .89

2. Normality of scientists

Coop learning

Control

35.154 .28

0.85

.402

36.264 .58

3. Attitude to scientific inquiry

Coop learning

1.39

.171

Control

36.935 .39

39.265 .90

4. Adoption of scientific attitudes

Coop learning

Control

38.524 .75

2.48

$.017^{\star}$

41.793 .85

5. Enjoyment of science lessons

Coop learning

Control

32.195 .93

2.51

$.016^{*}$

36.324 .77

6. Leisure interest in science

Coop learning

30.117 .58

2.54

$.015^{\star}$

Control

35.165 .00

7. Career interest in science

Coop learning

31.117 .57

1.46

.152

Control

34.004 .92

\footnotetext{
alaximum score $=30$. The higher the number the greater the cognition.

${ }^{b}$ Maximum score $=70$. The higher the number the more positive the attitude.

$p<.05$, two-tailed.
} 
The mean score differences (posttest-pretest scores) of the cognitive biology test and the TOSRA were compared between the cooperative learning group and the control group to evaluate the effect of the cooperative learning strategies in BSC $1005 \mathrm{~L}$ on community college students. No significant differences were shown in the mean score differences of the cognitive biology test or TOSRA scores between the cooperative learning group and the control group.

The test of the mean score differences of the cognitive biology test between the two groups was $\underline{p}=.107$. The test of the mean score differences of TOSRA scales: one resulted in $\underline{\underline{p}}=.598$; two resulted in $\underline{\underline{p}}=.341$; three resulted in $\mathrm{p}=.442 ;$ four resulted in $\mathrm{p}=.273$; five resulted in $\mathrm{Q}=.252$; six resulted in $\mathrm{p}=.283 ;$ and seven resulted in $\mathrm{g}=.288$ (see Table 4).

However, it is interesting to note that the cooperative learning group had a lower gain in the posttest cognitive biology test and TOSRA scale two (normality of scientists) scores than the control group. Also, the cooperative learning group had slightly more positive feelings about TOSRA scales: one (social implications of science), three (attitude to scientific inquiry), four (adoption of scientific attitudes), five (enjoyment of science lessons), six (leisure interest in science), and seven (career interest in science).

This data did not support the research hypotheses: (1) students who participate in the BSC $1005 \mathrm{~L}$ cooperative learning sections at an urban community college will perform significantly better on an instrument designed to measure attitudes toward science than those students who do not participate in 
the cooperative learning sections or (2) students who participate in the BSC 1005 L cooperative learning sections at an urban community college will perform significantly better on a cognitive biology instrument than those students who do not participate in the cooperative learning sections. 
Table 4

Mean Score Differences by Group.

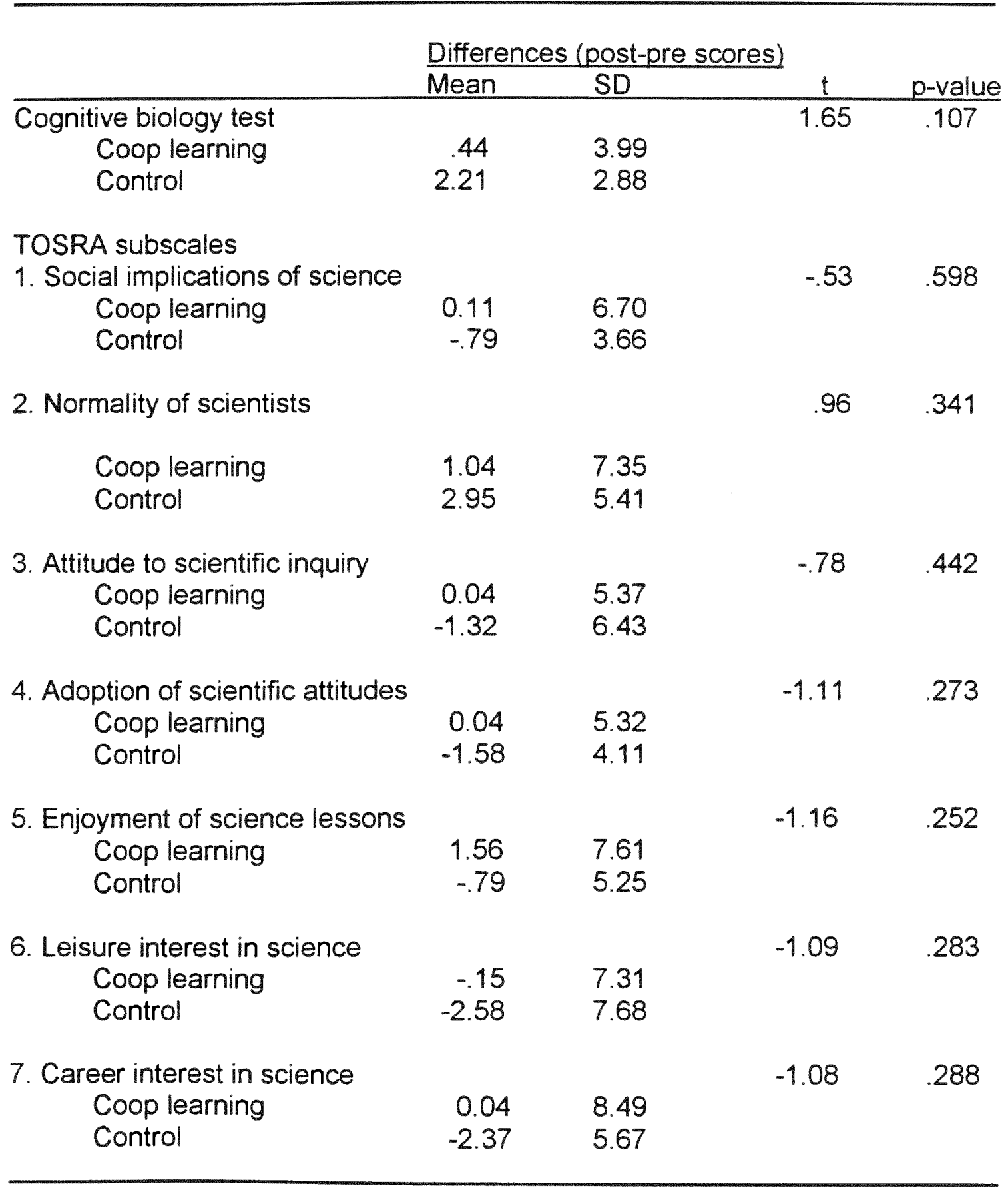


The cooperative learning group and the control group were considered individually from pretest to posttest. The t-tests did not show any significant differences in the mean score differences (posttest-pretest scores) of the cognitive biology test or TOSRA within the cooperative learning group. The test of the mean score differences of the cognitive biology test resulted in $\underline{p}=.568$. The test of the mean score differences of TOSRA scales: one resulted in $\mathrm{Q}=.932$, two resulted in $\mathrm{p}=.470$, three resulted in $\mathrm{p}=.972$, four resulted in $\underline{p}=971$, five resulted in $\underline{p}=29$, six resulted in $\underline{p}=.917$, and seven resulted in $\underline{p}=.982($ see Table 5).

However, it is interesting to note that the post mean scores of the cognitive biology test and the TOSRA scales: one (social implications of science), two (normality of scientists), three (attitude to scientific inquiry), four (adoption of scientific attitudes), five (enjoyment of science lessons), and seven (career interest in science) were slightly higher than the pretest scores within the cooperative learning group. This suggests that at the end of the study students in the cooperative learning group may have had somewhat more positive attitudes toward certain aspects of science. The post mean scores of the TOSRA scale six (leisure interest in science) were slightly lower than the pretest scores within the cooperative learning group (see Table 5). 
Table 5

Pre, Post, and Differences in Mean Scores Within the Cooperative Learning Group $\left(n_{1}=27\right)$.

\begin{tabular}{|c|c|c|c|c|c|c|}
\hline & $\frac{\text { Pre }}{\text { Mean }}$ & $\frac{\text { Post }}{\text { Mean }}$ & $\begin{array}{l}\text { Post-Pre } \\
\text { Mean }\end{array}$ & SD & $t$ & p-value \\
\hline $\begin{array}{l}\text { Cognitive biology test } \\
\text { TOSRA subscales }\end{array}$ & 10.41 & 10.85 & .44 & 1.74 & .58 & .568 \\
\hline 1. Social implications of science & 36.07 & 36.19 & .12 & -.20 & .09 & .932 \\
\hline 2. Normality of scientists & 35.15 & 36.19 & 1.04 & 1.41 & .73 & .470 \\
\hline 3. Attitude to scientific inquiry & 36.93 & 36.96 & .03 & .32 & .04 & .972 \\
\hline 4. Adoption of scientific attitudes & 38.52 & 38.56 & .04 & .37 & .04 & .971 \\
\hline 5. Enjoyment of science lessons & 32.19 & 33.74 & 1.55 & 3.43 & 1.06 & .298 \\
\hline 6. Leisure interest in science & 30.11 & 29.96 & -.15 & 1.99 & -.11 & .917 \\
\hline 7. Career interest in science & 31.11 & 31.15 & .04 & 2.09 & .02 & .982 \\
\hline
\end{tabular}

${ }^{a}$ Maximum score $=30$. The higher the number the greater the cognition.

${ }^{b}$ Maximum score $=70$. The higher the number the more positive the attitude. 
An analysis of the $t$ - test results of the mean score differences of the cognitive biology test and the TOSRA within the control group was also performed. Statistically significant differences were shown in the cognitive biology test, $\mathrm{p}=.004$ and the TOSRA scale two (normality of scientists), $\underline{p}=.029$. The post mean scores of these two items were higher than the pretest scores within the control group. At the end of the study the control group had improved their biology knowledge and more students thought scientists were normal. Statistical analysis of TOSRA scale seven resulted in $\underline{p}=.085$. This indicates that at the end of the study students in the control group had less interest in a science career than at the beginning. No indication of any significant differences was shown in the TOSRA scales: one, $p=.360$; three, $\underline{p}=.384$; four, $\mathrm{p}=.112$; five, $\mathrm{p}=.520$; or six, $\mathrm{p}=.161$. However, it should be noted that the post mean scores of TOSRA scales: one, three, four, five, and six were slightly lower than the pretest mean scores within the control group (see Table 6). At the end of the study the control group had learned more biology and more students thought scientists were normal. 
Table 6

Pre, Post, and Differences in Mean Scores Within the Control Group $\left(n_{2}=19\right)$.

\begin{tabular}{|c|c|c|c|c|c|c|}
\hline & $\frac{\text { Pre }}{\text { Mean }}$ & $\frac{\text { Post }}{\text { Mean }}$ & $\frac{\text { Post-F }}{\text { Mean }}$ & $\frac{\text { Pre }}{\text { SD }}$ & $t$ & p-value \\
\hline Cognitive biology test ${ }^{a}$ & 10.00 & 12.21 & 2.21 & .68 & 3.35 & $.004^{* *}$ \\
\hline $\begin{array}{l}\text { TOSRA subscales } \\
\text { 1. Social implications of science }\end{array}$ & 40.00 & 39.21 & -.79 & 1.68 & -.94 & .360 \\
\hline 2. Normality of scientists & 36.26 & 39.21 & 2.95 & .99 & 2.37 & $.029^{*}$ \\
\hline 3. Attitude to scientific inquiry & 39.26 & 37.95 & -1.31 & 1.21 & -.89 & .384 \\
\hline 4. Adoption of scientific attitudes & 41.79 & 40.21 & -1.58 & 1.29 & -1.67 & .112 \\
\hline 5. Enjoyment of science lessons & 36.32 & 35.53 & -.79 & 2.78 & -.66 & .520 \\
\hline 6. Leisure interest in science & 35.16 & 32.58 & -2.58 & 4.11 & -1.46 & .161 \\
\hline 7. Career interest in science & 34.00 & 31.63 & -2.37 & 3.21 & -1.82 & .085 \\
\hline
\end{tabular}

${ }^{a}$ Maximum score $=30$. The higher the number the greater the cognition.

${ }^{b}$ Maximum score $=70$. The higher the number the more positive the attitude.

${ }^{*} p<.05$, two-tailed. ${ }^{* *} p<.01$, two-tailed. 
The research data were further evaluated by performing the statistical procedure Analysis of Covariances (ANCOVAs). The post mean scores were adjusted for any differences in the pretest mean scores, ethnicity, gender, grade point average, and the number of absences. The ANCOVAs did not indicate any significant differences in the adjusted post mean scores of the cognitive biology test or the TOSRA between the two groups. The test of the adjusted post mean scores of the cognitive biology test resulted in $\mathrm{p}=.171$. The tests of the adjusted post mean scores of TOSRA scales: one resulted in $\mathrm{p}=.603$, two resulted in $\mathrm{p}=.130$, three resulted in $\mathrm{p}=.898$, four resulted in $\mathrm{p}=.895$, five resulted in $\mathrm{p}=.406$, six resulted in $\mathrm{p}=.484$, and seven resulted in $\mathrm{Q}=.462$ (see Table 7 ). It is interesting to note that after the adjustments the posttest mean scores changed little from the unadjusted posttest mean scores. 
Table 7

ANCOVA of the Post Scores Adjusted by the Pre Scores, Absences, Gender, Grade Point Average, and Ethnicity Between Groups.

Pre Post Adjusted

Mean Mean Post Mean $F$ p-value

Cognitive biology test $t^{a}$

Coop learning

Control

$\begin{array}{lll}10.41 & 10.85 & 10.82 \\ 10.00 & 12.21 & 12.26\end{array}$

$1.95 \quad .171$

TOSRA subscales ${ }^{b}$

1. Social implications of science

Coop learning

Control

2. Normality of scientists

Coop learning

Control

3. Attitude to scientific inquiry

Coop learning

Control

4. Adoption of scientific attitudes

Coop learning

Control

38.5238 .56

39.32

$41.7940 .21 \quad 39.13$

$\begin{array}{lll}36.93 & 36.96 & 37.47\end{array}$

$39.26 \quad 37.95 \quad 37.23$

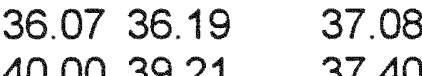

$\begin{array}{lll}35.15 & 36.19 & 36.32\end{array}$

$\begin{array}{lll}36.26 & 39.21 \quad 39.02\end{array}$

$2.40 \quad .130$

$.27 \quad .603$

$40.00-39.21-37.40$

5. Enjoyment of science lessons

Coop learning

Control

32.1933 .74

35.29

$36.32 \quad 35.53 \quad 33.33$

6. Leisure interest in science

Coop learning

Control

30.1129 .96

31.76

35.1632 .58

30.03

7. Career interest in science

Coop learning

Control
31.1131 .15 34.0031 .63
$.02 \quad .895$

.71 .406

$.50 \quad .484$

$.55 \quad .462$

\footnotetext{
${ }^{a}$ Maximum score $=30$. The higher the number the greater the cognition.

${ }^{b}$ Maximum score $=70$. The higher the number the more positive the attitude.
} 
The research data were also analyzed to identify any correlations between the cognitive biology test mean scores (pre, post, differences) and the TOSRA mean scores (pre, post, differences), absences, ethnicity, gender, and grade point average. This was done in order to address the research question regarding the correlation of attitudes toward science and biology achievement. Only grade point average was shown to have a statistically significant correlation with the pretest mean score of TOSRA scale four: $\underline{r}=.340, \underline{\mathrm{g}}=.021$, two-tailed. The greater the college grade point average the higher the pretest TOSRA scale four score (adoption of scientific attitudes). This suggests that the more academically successful a college student was, the greater their adoption of scientific attitudes. No significant correlations were identified between the cognitive biology test mean scores and the TOSRA mean scores. This data did not support research hypothesis (3): students with higher positive attitudes toward science will perform significantly better on a cognitive biology instrument than those students with low attitudes toward science.

Summary

The purpose of this study was to develop and evaluate the effectiveness of cooperative learning strategies in positively impacting the attitudes toward science and biology achievement of community college students. During the 1996-1997 academic year 2,207 students enrolled in BSC 1005L at the community college where the study was conducted. A review of the BSC 1005L data indicated that: (a) $398(18.03 \%)$ students withdrew from the course and (b) only $1,484(67.24 \%)$ successfully completed the course with a grade of $C$ or 
higher during the 1996-1997 academic year (K. Mascetti, personal communication, May 14, 1998).

It was established that at the beginning of the study the cooperative learning group and the control group had no significant differences in ethnicity, gender, or grade point average. A review of the number of absences during the term between the two groups also did not indicate a significant difference.

The following research hypotheses were tested:

1. Students who participate in the BSC $1005 \mathrm{~L}$ cooperative learning sections at an urban community college will perform significantly better on an instrument designed to measure attitudes toward science than those students who do not participate in the cooperative learning sections. The cooperative learning group had significantly lower pretest mean scores on the TOSRA scales: one (social implications of science), four (adoption of scientific attitudes, five (enjoyment of science lessons), and six (leisure interest in science) than the control group. The pretest mean scores of the TOSRA scales: two, three, and seven did not differ significantly between the cooperative learning and the control groups. At the end of the study it was found that the mean score differences from the pretest to posttest of the TOSRA scale two (normality of scientists) within the control group were significant. The post mean scores of the TOSRA scale two were significantly higher than the pretest mean scores within the control group. The TOSRA mean scores from pretest to posttest within the cooperative learning group did not differ significantly. No significant differences in the mean score differences (posttest-pretest scores) of the TOSRA were identified between the 
cooperative learning group and the control group. ANCOVAs did not indicate any significant differences in the adjusted post mean scores of the TOSRA between the two groups.

2. Students who participate in the BSC $1005 \mathrm{~L}$ cooperative learning sections at an urban community college will perform significantly better on a cognitive biology instrument than those students who do not participate in the cooperative learning sections. The pretest mean scores of the cognitive biology test did not differ significantly between the two groups. The mean score differences from the pretest to posttest of the cognitive biology test within the control group were determined to be significant. The post mean scores were significantly higher than the pretest mean scores within the control group. The cognitive biology test from pretest to posttest within the cooperative learning group did not differ significantly. No significant differences in the mean score differences (posttest-pretest scores) of the cognitive biology test were found between the cooperative learning group and the control group. ANCOVAs did not identify any significant differences in the adjusted post mean scores of the cognitive biology test between the two groups.

3. Students with higher positive attitudes toward science will perform significantly better on a cognitive biology instrument than those students with low attitudes toward science. Only grade point average was shown to have a statistically significant correlation with the pretest mean score of TOSRA scale four. The higher the college grade point average the greater the pretest TOSRA scale four score (adoption of scientific attitudes). No significant correlations were 
found between the cognitive biology test mean scores and the TOSRA mean scores in either the cooperative learning or control groups. The results of this study do not support research hypotheses one, two, or three. 


\section{CHAPTER FIVE}

Summary, Discussion, Conclusions, and Recommendations

This study was conducted in response to the need for empirical research evaluating the success of cooperative learning strategies in enhancing attitudes toward science and the cognitive biology knowledge of community college students. The inclusion of cooperative learning in BSC $1005 \mathrm{~L}$ was an attempt to increase the percentage of students successfully completing the general biology laboratory course for non-science majors at an urban community college. The experimental section of BSC $1005 \mathrm{~L}$ was restructured to provide students with opportunities to learn cooperative learning techniques. The review of the literature focused on collecting information about the best cooperative learning practices to be included in a higher education science laboratory course. This chapter summarizes and discusses the results of the study. Conclusions are presented followed by recommendations.

\section{Discussion of the results}

This study focused on whether incorporating cooperative learning strategies into BSC $1005 \mathrm{~L}$ would positively effect students' attitudes toward science and level of biology knowledge. The three research questions addressed were:

1. Will participation in the BSC $1005 \mathrm{~L}$ cooperative learning sections at an urban community college significantly increase students' positive attitudes toward science? 
2. Will participation in the BSC $1005 \mathrm{~L}$ cooperative learning sections at an urban community college significantly increase students' achievement in BSC 1005L?

3. Will those students with higher positive attitudes toward science perform better on a cognitive biology instrument than those students with low attitudes toward science?

A quasi-experimental pretest-posttest nonequivalent control group design was used. During the 1998 spring (January) term intact sections of BSC 1005L were randomly assigned to the cooperative learning group or the control group from the student population of an urban community college. Data were gathered about the sample by a demographic profile, pretest and posttest administration of the cognitive biology test and the Test of Science-Related Attitudes (TOSRA). The results of these instruments were analyzed to investigate the research questions.

Chi square tests and t-tests established that the two groups had no significant differences in ethnicity, gender, grade point average, or absences during the study. The cooperative learning group had significantly lower pretest mean scores on the TOSRA scales: one (social implications of science), four (adoption of scientific attitudes), five (enjoyment of science lessons), and six (leisure interest in science) than the control group. College grade point average was identified as being significantly correlated with the pretest mean score of TOSRA scale four (adoption of scientific attitudes). No significant correlation between attitudes toward science and cognitive biology achievement was shown. 
The pretest mean scores of the cognitive biology test and the TOSRA scales: two, three, and seven did not differ significantly between the cooperative learning and the control group.

I-tests at the end of the study determined that the mean scores from pretest to posttest of the cognitive biology test and the TOSRA scale two (normality of scientists) within the control group were statistically significantly different. The posttest mean scores of these two items were significantly higher than the pretest mean scores within the control group. By the end of the study students in the control group seemed to have increased their biology knowledge and their perception that scientists were normal people. The TOSRA scale seven posttest mean scores were slightly different. The interest of the control group students in a science career may have decreased during the study. The posttest mean scores of TOSRA scales: one, three, four, five, six, and seven were slightly lower than the pretest scores within the control group. The control group students may have developed more negative feelings about the social implications of science, attitude to scientific inquiry, adoption of scientific attitudes, enjoyment of science lessons, leisure interest in science and career interest in science during the study. The cognitive biology test and TOSRA mean scores from pretest to posttest within the cooperative learning group did not differ significantly. However, it is interesting to note that the posttest mean scores on the cognitive biology test and TOSRA scales: one, two, three, four, five, and seven were slightly higher than the pretest scores within the cooperative learning group. Although this rise was not statistically significant at $\alpha=.05$, it shows a trend of 
improvement which bears further investigation. It could be argued that improvement in attitudes toward science may contribute to greater biology knowledge. However, it may require more time than was available in this study for this shift in attitudes toward science to evidence itself in higher levels of cognitive biology knowledge. Analysis of Covariances in which the posttest scores were adjusted for any differences in the pretest scores (ethnicity, gender, grade point average) did not identify any significant differences in the adjusted posttest means of the cognitive biology test or the TOSRA between the cooperative learning group and the control group.

\section{Conclusions}

The findings of this study do not support the research hypotheses:

1. Students who participate in the BSC $1005 \mathrm{~L}$ cooperative learning sections at an urban community college will perform significantly better on an instrument designed to measure attitudes toward science than those students who do not participate in the cooperative learning sections.

2. Students who participate in the BSC $1005 \mathrm{~L}$ cooperative learning sections at an urban community college will perform significantly better on a cognitive biology instrument than those students who do not participate in the cooperative learning sections.

3. Students with higher positive attitudes toward science will perform significantly better on a cognitive biology instrument than those students with low attitudes toward science. 
However, the slight increases in the cooperative learning group from the pretest to the posttest cognitive biology test and TOSRA scales: one, two, three, four, five, and seven indicate that further empirical research is needed. These results suggest that cooperative learning strategies may be beneficial to students in BSC 1005L.

The elements identified as key to effective cooperative learning in higher education were: (a) positive interdependence among group members, (b) individual accountability, (c) a rationale for grouping, (d) structured student interaction, $(e)$ instructor monitoring and facilitation, and (f) explicit attention to social skills and group processing. Cook (1991) concluded that even college students needed to be taught group social skills. Mastery of these skills are crucial in developing a well functioning team. College students must be able to

(a) build teams, (b) solve problems verbally, (c) support academic tasks, (d) provide social support, and (e) perform group evaluations in order to achieve the benefits of cooperative learning. This study endeavored to incorporate the key elements and social skills of cooperative learning into the experimental sections of BSC 1005L. A posthoc analysis indicated that the benefits of cooperative learning may not have been realized in this study due to:

(1) instructor inexperience with cooperative learning and (2) time constraints. Instructor experience.

Based on 25 years of cooperative learning research Johnson and Johnson (1992) determined that effective implementation requires three to five years of training. Although the instructor in this study had taught BSC 1005 and BSC 
$1005 \mathrm{~L}$ at this community college for more than eight years she had no prior experience using cooperative learning as an instructional method. Her lack of cooperative learning mastery may partially explain the study's inability to demonstrate a positive significant effect when cooperative learning was used in BSC 1005L. No significant difference was identified in attitudes toward science or cognitive biology knowledge when cooperative leaming was implemented in the non-science majors' community college course. No correlation was shown between attitudes toward science and biology achievement. Although the researcher met with the instructor weekly to discuss cooperative learning the instructor may have needed more time to learn, practice, and become skilled in training students to learn cooperatively. The researcher observed the instructor weekly in the cooperative learning sections of BSC 1005L. The researcher concluded that greater instructor proficiency in: (a) teaching cooperative learning techniques; (b) evaluating each student's ability to share ideas and information, modify and use different viewpoints, keep their group on task, compliment and encourage the participation of group members, teach other group members, and to ensure that all group members understand what was taught; (c) monitoring student practice of cooperative learning techniques; and (d) providing immediate feedback may have more positively effected the study. Previous research has documented that the more able an instructor is in doing this the greater the achievement will be in cooperative learning groups. 


\section{Time constraints.}

The complete study design was unable to be implemented due to time constraints. Time limits were created by (a) changes in the biology laboratory procedures which required more instructor time to set up and solve logistical problems, (b) the greater time students needed to complete all the biology laboratory experiments, (c) the longer instructor time required to implement the cooperative learning elements, and (d) the prolonged time students needed to practice the cooperative learning strategies.

Students needed more time to (a) team build; (b) wrap-up laboratory sessions (group discussion of biology experiment results, individual oral summary of group's biology experiments); and (c) group process the evaluation forms (students analyze and discuss how well the group is working together, identify the member actions that are helpful, and describe what to continue or change to improve the group's interaction and effectiveness). These components are influential in maximizing group productivity and individual achievement. The limited ability of students in the cooperative learning sections to accomplish these steps may partially explain why no significant difference was found in the mean score differences (posttest-pretest scores) cognitive biology test or TOSRA between the cooperative learning group and the control group. 


\section{Recommendations}

A review and analysis of the experiment indicate that the following should be done:

1. Information about the research findings of this cooperative learning study should be disseminated throughout this urban community college to encourage other faculty to consider this instructional approach.

2. A Staff and Program Development proposal should be written to fund two cooperative learning workshops at this institution. Workshop one would feature Dr. Susan Hill, the Director of the Southeastern Center for Cooperative Learning and Dr. Kenneth Whitten, Professor of Computer/Office System at the Florida Community College of Jacksonville. The basic concepts of the Johnson model of cooperative learning as a structured classroom strategy and the three types of cooperative groups would be explored. Also, the rationale for using cooperative learning in college settings would be discussed. Workshop two would utilize two speakers with extensive experience in using cooperative learning in the college classroom. The exploration of cooperative learning as a strategy for promoting active learning environments would be continued. Activities would focus on the fundamentals of the Johnson model, the five basic elements needed for successful groups, and techniques for structuring informal and formal groups. An overview of the professor's role in a cooperative college classroom and current research would be discussed. Also, 
faculty who had been involved in this cooperative learning study would be invited to share their experiences.

3. A Staff and Program Development proposal should be written to fund cooperative learning research at this urban community college. Faculty would be given three release hours over one academic year to (a) attend the cooperative learning workshops, (b) redesign an academic course into a cooperative learning format, (c) implement the redesigned course for one academic term, (d) evaluate the effect of cooperative learning in the course, and (e) disseminate the results to faculty and staff throughout the institution to encourage the use of cooperative learning.

4. A Staff and Program Development proposal should be written to fund evaluation of cooperative learning at this community college. Faculty would be given two release hours over one academic year to (a) implement an academic course that had been redesigned to include cooperative learning techniques for one academic term, (b) compare the results of the redesigned course to those of an equivalent course which have not been redesigned, (c) disseminate the results to faculty and staff throughout the institution to encourage the use of cooperative learning. Faculty would be divided into two groups. Those who had less than three years cooperative learning experience and those that had more than three years cooperative learning experience at the community college level. 
5. A Staff and Program Development proposal should be written to fund coordination of cooperative learning research at this institution. Three release hours would be given each academic year for two years to (a) organize the cooperative learning workshops, (b) recruit faculty into cooperative learning research, (c) develop and implement faculty workshops on redesigning academic courses to include cooperative learning techniques, (d) coordinate evaluation of the redesigned courses, (e) evaluate the impact of an instructor's length of cooperative learning experience on student achievement, (f) disseminate the research findings throughout the institution, and $(\mathrm{g})$ coordinate presentations by cooperative learning participants to faculty and staff.

\section{Implications for Future Research}

A review of the literature and the results of this study suggest the following implications for future research:

1. The slight increase in the cooperative learning group from the pretest to the posttest cognitive biology test and TOSRA scales: one (social implications of science, two (normality of scientists), three (attitude to scientific inquiry), four (adoption of scientific attitudes), five (enjoyment of science lessons, and seven (career interest in science) suggest that cooperative learning strategies may positively affect attitudes to science and cognitive biology knowledge in BSC 1005L. However, the design of the BSC 1005L cooperative learning experiment should be altered. The modifications would include: (a) an instructor who has 
three years or more community college cooperative learning experience and is more able to facilitate and monitor cooperative learning; (b) only those biology laboratory procedures that have incorporated into BSC $1005 \mathrm{~L}$ for at least one academic year; (c) a decrease in the number of biology laboratory experiments required each session; (d) provision of student team leader training; and (e) an increase in the laboratory time available for student practice of team building, social skills, oral and written laboratory reports, and group processing.

2. Future studies of a community college cooperative learning design would have greater generalizability if more students and other community college courses were included. This would be possible if faculty from other academic disciplines were encouraged to participate in cooperative learning research at this institution.

3. Future studies of a community college cooperative learning design could evaluate whether there is a significant difference if the instructor has less than college cooperative learning experience or more than three years of college cooperative learning experience.

4. Future research using qualitative methods (e.g. observations and interviews) could gather data regarding an instructor's ability to: (a) teach cooperative learning techniques; (b) asses each student's skill in sharing information and ideas, modifying and using other perspectives, keeping their group focused, supporting the active 
involvement of all group members, educating other group members, and confirming that all group members understand what was taught;

(c) monitor student use of cooperative learning techniques; and (d) provide timely feedback. Other possible research areas could include (a) how specific cooperative learning techniques implemented in community college courses affect students, (b) how an individual student incorporates and refines specific cooperative learning strategies, or (c) why a student would choose not to use cooperative learning strategies.

The appropriate incorporation of cooperative learning into the community college classroom may increase students' active learning, enjoyment of the subject, and content mastery. However, much more empirical research is needed to aid in the understanding, development, and improvement of cooperative learning at the community college level. 
Abraham, M. R. (1989). Research on instructional strategies. Journal of College Science Teaching. 18 (3), 185-187, 200.

Aronson, E. \& Patnoe, S. (1997). The jigsaw classroom (2nd ed.). New York: Longman.

Basili, P. A. \& Sanford, J. P. (1991). Conceptual change strategies and cooperative group work in chemistry. Journal of Research in Science Teaching. 28 (4), 293-304.

Bier, J. (1993). Realizations of a chemistry educator. Joumal of College Science Teaching, 22, 291-294.

Billson, J.M. (1986). The college classroom as a small group: Some implications for teaching and learning. Teaching Sociology, 14 (3), 143-151.

Bollen, F. A. (1972). Attitude assessment in science teaching. The School Science Review, 54, 217-235.

Bruening, T. (1990). Cooperative learning as a teaching strategy. The Agricultural Education Magazine, 63, 12-14.

Bybee, R. W. \& DeBoer, G. E. (1994). Research on goals for the science curriculum. In D. L. Gabel (Ed.), Handbook of research on science teaching and learning (pp. 357-387). New York:Macmillan Publishing Company.

Bykerk-Kaufman, A. (1995). Using cooperative learning in college geology classes. Journal of Geological Education, 43, 309-316.

Caprio, M. W. (1993). Cooperative learning - the jewel among motivational teaching techniques. Journal of College Science Teaching, 22, 279281.

Cohen, E. G. (1990). Teaching in multiculturally heterogeneous classrooms:

Findings from a model program. McGill Journal of Education, 26 (2), 7-23.

Cohen, E. G. (1994). Restructuring the classroom: Conditions for productive small groups. Review of Educational Research. 64 (1), 1-35.

Cohen, E. G. (1994). Designing group work (2nd ed.). New York: Teachers College Press. 
Cook, L. (1991). Cooperative learning: a successful college teaching strategy. Innovative Higher Education, 16 (1), 27-38.

Cooper, J. (1990). Cooperative learning and college teaching: Tips from the trenches. The Teaching Professor, 4 (5).

Cooper, J. (1992). What is cooperative learning? Cooperative Learning \& College Teaching, 3 (1), 2.

Cooper, J. \& Mueck, R. (1989). Cooperative/collaborative learning: Research and practice (primarily) at the collegiate level. Journal of Staff. Program \& Organization Development. 7 (3), 143-147.

Cooper, J. \& Mueck, R. (1990). Student involvement in learning: Cooperative learning and college instruction. Journal of Excellence in College Teaching. 1, 68-76.

Cooper, M. (1993). Cooperative chemistry laboratories. Cooperative Learning. $13,37$.

Cooper, M. (1994). Cooperative chemistry laboratories. Journal of Chemical Education, 71 (4) 307.

Cooper, M. (1995). Cooperative learning. An approach for large enrollment courses. Journal of Chemical Education, 72 (2), 162-164.

Courtney, D. P., Courtney, M. \& Nicholson, C. (1994). The effect of cooperative learning as an instructional practice at the college level. College Student Journal, 28 (4), 471-477.

Cuseo, J. (1992). Cooperative learning: Why does it work? Cooperative Learning \& College Teaching, 3 (1), 3-4, 8.

Cuseo, J. (1993). The practices of cooperative learning: Key implementation questions and decisions. Cooperative Learning \& College Teaching. 4 (1), 3-6.

Davidson, N. \& O'Leary, P. W. (1990). How cooperative learning can enhance mastery teaching. Educational Leadership 47, 30-33.

Deavor, J. P. (1994). Role-playing in the quantitative analysis lab. Journal of Chemical Education, 71 (11), 980-981. 
Feichtner, S. B. \& Davis, E. A. (1984-5). Why some groups fail: A survey of students' experiences with learning groups. The Organizational Behavior Teaching Review, 9 (4), 58-71.

Fleming, F. F. (1995). No small changes: simultaneously introducing cooperative learning and microscale experiments in an organic lab course. Journal of Chemical Education, 72 (8), 719-720.

Foyle, H. C. (Ed.). (1995). Interactive learning in the higher education classroom: Cooperative, collaboration, and active learning strategies. Washinton, D. C.: National Education Association.

Fraser, B. F. (1978). Development of a test of science-related attitudes. Science Education, 62 (4), 509-515.

Fraser, B. J. (1981). TOSRA: Test of science-related attitudes handbook. Victoria, Australia: The Australian Council for Educational Research Limited.

Gardner, P. L. (1975). Science curricula and attitudes to science: A review. The Australian Science Teachers Journal, 21 (2), 23-40.

Gauld, C. F. \& Hukins, A. A. (1980). Scientific attitudes: A review. Studies in Science Education, 7, 129-161.

George, P. G. (1994). The effectiveness of cooperative learning strategies in multicultural university classrooms. Journal on Excellence in College Teaching, 5 (1), 21-30.

Goodsell, A. S., Maher, M. R., Tinto, V., Smith, B. L. \& MacGregor, J. (1992). Collaborative learning: A sourcebook for higher education. University Park, PA: National Center on Postsecondary Teaching, Learning, and Assessment.

Haney, R. E. (1964). The development of scientific attitudes. The Science Teacher, 31, 33-35.

Haukoos, G. D. \& Penick, J. E. (1983). The influence of classroom climate on science process and content achievement of community college students. Journal of Research in Science Teaching, 20 (7), 629-637.

Heller, R. \& Hollabaugh, M. (1992). Teaching problem solving through cooperative grouping. Part 2: Designing problems and structuring groups. American Journal of Physics, 60 (7), 637-644. 
Hertz-Lazarowitz, R. \& Miller, N. (1992). Interaction in cooperative groups: The theoretical anatomy of group learning. Cambridge: Cambridge University Press.

Hofstein, A. \& Lunetta, V. N. (1982). The role of the laboratory in science teaching: Neglected aspects of research. Review of Educational Research, 52 (2), 201-217.

Hufford, T. L. (1991). Increasing academic performance in an introductory biology course. BioScience, 41 (2), 107-108.

Johnson, D. W. \& Johnson, F. P. (1997). Joining together: Group theory and group skills $\left(6^{\text {th }}\right.$ ed.). Boston: Allyn and Bacon.

Johnson, D. W. \& Johnson, R. T. (1992). Implementing cooperative learning. Contemporary Education, 63 (3), 173-181.

Johnson, D. W., Johnson, R. T., \& Smith, K. A. (1990). Cooperative learning: An active learning strategy for the college classroom. Baylor Educator, 15 (2), 11-16.

Johnson, D. W., Johnson, R. T., \& Smith, K. A. (1991). Active learning: Cooperation in the college classroom. Edina, MN: Interaction Book Company.

Johnson, D. W., Johnson, R. T., \& Smith, K. A. (1991). Cooperative learning: Increasing college faculty instructional productivity. (ASHE-ERIC Higher Education Report No. 4). Washington,D.C.: George Washington University.

Johnson, D. W., Johnson, R. T. \& Stanne, M. B. (1989). Impact of goal and resource interdependence on problem-solving success. The Journal of Social Psychology, 129 (5), 621-629.

Johnson, D. W., Johnson, R. T., Stanne, M. B. \& Garibaldi, A. (1989). Impact of group processing on achievement in cooperative groups. The Journal of Social Psychology, 130 (4), 507-516.

Kandel, M. (1994). Personalized lab experiences through cooperative projects. Journal of Chemical Education, 71 (6), 513.

Klionsky, D. J. (1998). A cooperative learning approach to teaching introductory biology. Journal of College Science Teaching, 27 (5), 334-338. 
Klopfer, L. E. (1976). A structure for the affective domain in relation to science education. Science Education, 60 (3), 299-312.

Koballa, Jr., T. R. \& Crawley, F. E. (1985). The influence of attitude on science teaching and learning. School Science and Mathematics, 85 (3), 222-232.

Lawson, A. E. (1992). Using reasoning ability as the basis for assigning laboratory partners in nonmajors biology. Journal of Research in Science Teaching, $29(7), 729-741$.

Leonard, W. H. (1991). A recipe for uncookbooking laboratory investigations. Journal of College Science Teaching, 21, 84-87.

Lunetta, V. \& Hofstein, A. (1991). Simulation and laboratory practical activity. In B. E. Woolnough (Ed.), Practical science: the role and reality of practical work in school science. (pp. 125-137). Buckingham, England: Open University Press.

Martin, G. D. (1995). Cooperative learning in chemistry tutorials. Assessing the effectiveness of group learning strategies. Journal of College Science Teaching. 25 (1), 20-23.

Maruyama, G. (1991). Meta-analyses relating goal structures to achievement: Findings, controversies, and impacts. Personality and Social Psychology Bulletin, 17 (3), 300-305.

Mason, C. L. (1992). Concept mapping: A tool to develop reflective science instruction. Science Education, 76 (1), 51-63.

Millis, B. J. (1990). Helping faculty build learning communities through cooperative groups. To Improve the Academy, 9, 43-58.

Mills, V. (1981). The investigative laboratory in introductory biology courses: A practical approach. The American Biology Teacher, 43 (7), 364-367.

Munby, H. (1983). Thirty studies involving the "Scientific Attitude Inventory": What confidence can we have in this instrument? Journal of Research in Science Teaching. 20 (2), 141-162.

Natasi, B. K. \& Clements, D. H. (1991). Research on cooperative learning: Implications for practice. School Psychology Review, 20 (1), 110-131.

Nattiv, A., Winitzky, N. \& Drickey R. (1991). Using cooperative learning with preservice elementary and secondary education students. Journal of Teacher Education, 42 (3), 216-225. 
Nuffield Foundation. (1977). Practical work in undergraduate science. London: Heinemann Educational Books Limited.

Nuffield Foundation. (1977). Small group teaching in undergraduate science. London: Heinemann Educational Books Limited.

Obler, S., Arnold, V., Sigala, C., \& Umbdenstock, L. (1991). Using cooperative learning and classroom research with culturally diverse students. In T. Angelo (Ed.), Classroom research: Early lessons from success (pp. 105-116). San Francisco: Jossey-Bass.

Okebukola, P. A. (1986). Cooperative learning and students' attitudes to laboratory work. School Science and Mathematics, 86 (7), 582-590.

Phillippe, K. (Ed.). (1997). National profile of community colleges: Trends \& Statistics 1997-1998. Washington D. C.: Community College Press.

Purdom, D. M. \& Kromrey, J. D. (1995). Adapting cooperative learning strategies to fit college students. College Student Journal, 29 (1), $57-64$.

Rau, W. \& Sherman-Heyl, B. (1990). Humanizing the college classroom: Collaborative learning and the social organization among students. Teaching Sociology. 18, 141-155.

Roueche, J. E. \& Roueche, S . D. (1993). Between a rock and a hard place. Washington, D.C.: Community College Press.

Saunders, W. L. \& Dickinson, D. H. (1979). A comparison of community college students' achievement and attitude changes in a lecture-only and lecturelaboratory approach to general education biological science courses. Journal of Research in Science Teaching. 16 (5), 459-464.

Schibeci, R. A. (1983). Selecting appropriate attitudinal objectives for school science. Science Education, 67 (5), 595-603.

Schibeci, R. A. (1984). Attitudes to science: an update. Studies in Science Education, 11, 26-59.

Sharan, S. (Ed.). (1990). Cooperative learning:Theory and research. New York: Praeger.

Shrigley, R. L. (1983). The attitude concept and science teaching. Science Education, 67 (4), 425-442. 
Shulman, L. S. \& Tamir, P. (1973). Research on teaching in the natural sciences. In R. M. Tavers (Ed.), Second handbook of research on teaching (pp.1098-1140). Chicago: Rand McNally.

Slavin, R. E. (1990). Cooperative learning: Theory, research and practice. Englewood Cliffs, NJ: Prentice Hall.

Slavin, R. E. (1991). Student team learning: A practical guide to cooperative learning. Washington, D.C.: National Education Association.

Slavin, R. E. (1991). Synthesis of research on cooperative learning. Educational Leadership, 48 (5), 71-77, 79-82.

Slavin, R. E. (1993). What can post-secondary cooperative learning learn from elementary and secondary research. Cooperative Learning and College Teaching, 4 (1), 2-3.

Slavin, R., Sharan, S., Kagan, S., Hertz-Lazarowitz, R., Webb, C., \& Schmuck, R. (Eds.). (1985). Learning to cooperate, cooperating to learn. New York: Plenum.

Smith, M E., Hinckley, C. C., \& Volk, G. L. (1991). Cooperative learning in the undergraduate laboratory. Journal of Chemical Education, 68 (5), 413415.

Stefani, L. A. J. \& Tariq, V. N. (1996). Running group practical projects for firstyear undergraduate students. Journal of Biological Education, 30 (1), 3644.

Temperly, D. S. (1994). Cooperative learning in the community college classroom. Journal of College Science Teaching. 24 (2), 94-97.

Tewksbury, B. J. (1995). Specific strategies for using the "jigsaw" technique for working in groups in non-lecture based courses. Journal of Geological Education, 43, 322-326.

Tinto, V. \& Russo, P. (1994). Coordinated studies programs: Their effect on involvement at a community college. Community College Review, 22 (2), 16-25.

Tobin, K., Tippins, D. J., \& Gallard, A. J. (1994). Research on instructional strategies for teaching science. In D. L. Gabel (Ed.), Handbook of research on science teaching and learning (pp. 45-93). New York: Macmillan Publishing Company. 
Trautwein, S. N., Racke, A., \& Hillman, B. (1997). Cooperative learning in the anatomy laboratory. Journal of College Science Teaching. 20 (3), 183188.

Varco-Shea, T. C., Darlington, J., \& Turnbull, M. (1996). Group project format in first-semester general chem lab. Journal of Chemical Education, 73 (6), 536-538.

Vermette, P. J. \& Erickson, D. B. (1996). Cooperative learning in the college classroom: Three structures and seven activities. College Student Journal, 30 (2), 203-213.

Wallace, J. (1995). Cooperative learning in college classrooms: Getting started. College Student Journal, 29 (4), 458-459.

Weinstein, C. E., Meyer, D. K., \& Van Mater Stone, G. (1994). Teaching students how to learn. In W. J. McKeachie, N. Chism, R. Menges, M. Svinicki, \& C. E. Weinstein, Teaching tips: Strategies, research, and theory for college and university teachers (9th ed.). (pp.359-367). Lexington, MA: D. C. Heath.

Whipple, W. R. (1987). Collaborative learning: Recognizing it when we see it. American Association for Higher Education Bulletin, 40, 3-7.

Wilson, V. L. (1983). A meta-analysis of the relationship between science achievement and science attitude: kindergarten through college. Journal of Research in Science Teaching, 20 (9), 839-850. 


\title{
TEST OF SCIENCE-RELATED ATTITUDES
}

\author{
Barry J. Fraser
}

\section{DIRECTIONS}

1 This test contains a number of statements about science. You will be asked what you yourself think about these statements. There are no 'right' or 'wrong' answers. Your opinion is what is wanted.

2 All answers should be given on the separate Answer Sheet. Please do not write on this booklet.

3 For each statement, draw a circle around

SA if you STRONGLY AGREE with the statement;

A if you AGREE with the statement;

$N$ if you are NOT SURE;

$D$ if you DISAGREE with the statement;

SD if you STRONGLY DISAGREE with the statement.
Practice Item

- It would be interesting to learn about boats.

Suppose that you AGREE with this statement, then you would circle A on your Answer Sheet, like this:

$\begin{array}{llllll}0 & \mathrm{SA} & \text { (A) } & \mathrm{N} & \mathrm{D} & \mathrm{SD}\end{array}$

4 If you change your mind about an answer, cross it out and circle another one.

5 Although some statements in this test are fairly similar to other statements, you are asked to indicate your opinion about all statements.

Published by

The Australian Council for Educational Research Limited

Radford House, Frederick Street, Hawthorn, Victoria 3122

Typesetting direct from Wang diskette by

Publication Perspectives

200 Cheitenham Road, Dandenong, Victoria 3175

Printed by Allanby Press

1A Crescent Road, Camberwell, Victoria 3124

Copyright $\odot$ B.J. Fraser 1981

The materials in this publication may not be reproduced without permission from the publisher with the below-men* tioned exception:

After the initial purchase and supply of the materials to a recognized educational establishment copies may be made and used within that establishment without the requirement of the payment of a fee subject to the condition that they are not made available to users by way of trade or sale.

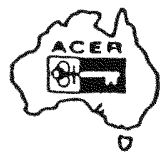

Australian Council for Educational Research 
1 Money spent on science is well worth spending.

2 Scientists usually like to go to their laboratories when they have a day off.

3 I would prefer to find out why something happens by doing an experiment than by being told.

4 I enjoy reading about things which disagree with my previous ideas.

5 Science lessons are fun.

6 I would like to belong to a science club.

7 I would dislike being a scientist after I leave school.

8 Science is man's worst enemy.

9 Scientists are about as fit and healthy as other people.

10 Doing experiments is not as good as finding out information from teachers.

11 I dislike repeating experiments to check that I get the same results.

12 I dislike science lessons.

13 I get bored when watching science programs on TV at home.

14 When I leave school, I would like to work with people who make discoveries in science.

15 Public money spent on science in the last few years has been used wisely.

16 Scientists do not have enough time to spend with their families.

17 I would prefer to do experiments than to read about them.

18 I am curious about the world in which we live.

19 School should have more science lessons each week.

20 I would like to be given a science book or a piece of scientific equipment as a present.

21 I would dislike a job in a science laboratory after Il leave school.

22 Scientific discoveries are doing more harm than good.

23 Scientists like sport as much as other people do.

24 I would rather agree with other people than do an experiment to find out for myself.

25 Finding out about new things is unimportant.

26 Science lessons bore me.

27 I dislike reading books about science during my holidays.

28 Working in a science laboratory would be an interesting way to earn a living. 
29 The government should spend more money on scientific research.

30 Scientists are less friendly than other people.

31 I would prefer to do my own experiments than to find out intormation from a teacher.

32 I like to listen to people whose opinions are different from mine.

33 Science is one of the most interesting school subjects.

34 I would like to do science experiments at home.

35 A career in science would be dull and boring.

36 Too many laboratories are being built at the expense of the rest of education.

37 Scientists can have a normal family life.

38 I would rather find out about things by asking an expert than by doing an experiment.

39 I find it boring to hear about new ideas.

40 Science lessons are a waste of time.

41 Talking to friends about science after school would be boring.

42 I would like to teach science when I leave school.

43 Science helps to make life better.

44 Scientists do not care about their working conditions.

45 I would rather solve a problem by doing an experiment than be told the answer.

46 In science experiments, I like to use new methods which I have not used before.

47 I really enjoy going to science lessons.

48 I would enjoy having a job in a science laboratory during my school holidays.

49 A job as a scientist would be boring. 
50 This country is spending too much money on science.

51 Scientists are just as interested in art and music as other people are.

52 It is better to ask the teacher the answer than to find it out by doing experiments.

53 I am unwilling to change my ideas when evidence shows that the ideas are poor.

54 The material covered in science lessons is uninteresting.

55 Listening to talk about science on the radio would be boring.

56 A job as a scientist would be interesting.

57 Science can help to make the world a better place in the future.

58 Few scientists are happily married.

59 I would prefer to do an experiment on a topic than to read about it in science magazines.

60 In science experiments, I report unexpected results as well as expected ones.

61 Ilook forward to science lessons.

62 I would enjoy visiting a science museum at the weekend.

63 I would dislike becoming a scientist because it needs too much education.

64 Money used on scientific projects is wasted.

65 If you met a scientist, he would probably look like anyone else you might meet.

66 It is better to be told scientific facts than to find them out from experiments.

67 I dislike listening to other people's opinions.

68 I would enjoy school more if there were no science lessons.

69 I dislike reading newspaper articles about science.

70 I would like to be a scientist when I leave school. 
1. Atoms that bear a positive or negative charge are known as:
A. magnetic
B. electrically neutral
C. ions
D. lacking nuclei

2. Choose the membrane molecule responsible for aiding passage of polar molecules into and out of the cell.
A. phospholipids
C. transmembrane proteins
B. cell surface proteins
D. carbohydrate chains

3. The nucleotide sequences on DNA that actually have information encoding a sequence of amino acids are:
A. introns
B. exons
C. proteins
D. enhancers

4. In small populations, gene frequencies can change drastically by chance alone. This phenomenon is called:
A. migration
C. density-dependent effects
B. density-independent effects
D. genetic drift

5. Select the membrane molecule that is made up of a polar region with two nonpolar fatty acid tails.
A. phospholipids
B. cell surface proteins
C. transmembrane proteins
D. carbohydrate chains

6. The fossil record indicates that whales evolved from:
A. hoofed mammals
B. fish
C. sharks
D. dinosaurs

7. The cell manufactures proteins on its:
A. nucleolus
B. endoplasmic reticulum
C. Golgi complex
D. ribosomes

8. The bases of RNA are the same as those of DNA with the exception that RNA contains:
A. cysteine instead of cytosine
B. uracil instead of thymine
C. cytosine instead of guanine
D. phenylalanine instead of adenine

9. After Joseph Farnam discovered, in 1985, that an ozone hole was developing over Antarctica, scientists measured levels of chemicals in the upper atmosphere. They found a surprising concentration of ozone-destroying:
A. chlorine
B. helium
C. nitrates
D. mercury

10. Biochemist Erwin Chargaff found that in DNA there was a special relationship between individual bases that we now refer to as Chargaff's rule. His observation was that:
A. $A=T$ and $G=C$
B. $C=T$ and $A=G$
C. purines are always paired
D. pyrimidines are always paired 
11. In the human $A B O$ blood grouping, there are four basic blood types, type

$A$, type $B$, type $A B$, and type $O$. The blood proteins $A$ and $B$ are:

A. simple dominant and recessive traits

B. codominant

C. incompletely dominant

D. sex-linked traits

12. Which of the following is NOT an underlying theme of biology?
A. cooperation
B. flow of energy
C. evolution
D. creation

13. Light energy arrives at earth in little packets called:
A. antrums
B. photons
C. light waves
D. wavelengths

14. The building blocks of carbohydrates are:
A. amino acids
C. monosaccharides
B. polypeptides
D. nucleotides

15. Bacterial cells divide by:
A. mitosis
B. cleavage
C. cytokinesis
D. binary fission

16. If several traits are affected by the same allele, the allele is said to be:
A. recessive
B. dominant
c. epistatic
D. pleiotropic

17. Cells of the immune system recognize normal body cells by what kind of membrane protein?
A. channel proteins
C. coupled channels
B. receptor proteins
D. voltage-sensitive channels

18. Cilia and flagella differ from each other primarily in:
A. function
C. internal structure
B. length
D. internal chemistry

19. In snapdragons, pink-flowered plants are produced when red-flowered plants and crossed with white-flowered plants. This type of inheritance can best be described as:
A. simple dominant and recessive traits
B. codominance
C. incomplete dominance
D. sex-linked traits

20. The notion that organisms that are more distantly related should have time to accumulate more biochemical differences than those more closely related can best be illustrated using a:
A. radioactive isotope dating
B. gel electrophoresis
C. geologic time scale
D. molecular clock 
21. The hypothesis that suggests evolution occurs in spurts, with a great deal of evolutionary activity followed by periods of slower evolution is:
A. the cell theory
B. punctuated equilibrium
C. gradualism
D. Hardy-Weinberg equilibrium

22. Scientists employ scientific process. reasoning when performing the
A. inductive
B. deductive
c. reductive
D. adductive

23. DNA is made up of building blocks called:
A. proteins
B. bases
c. nucleotides
D. acids

24. Fatty acids that contain the maximum number of hydrogen atoms possible are said to be:
A. polyunsaturated
B. monounsaturated
C. saturated
D. phospholipids

25. The volume of space around a nucleus where an electron is most likely to be located is called the of that electron.
A. energy level
B. spin
C. pathway
D. orbital

26. How many different species of bacteria have so far been recognized?
A. 150
B. 2,500
C. 15,000
D. 25,000

27. Making and breaking molecules in the body requires the aid of to help the reactions proceed.
A. heat
B. water
C. blood
D. enzymes

28. During photosynthesis, ATP molecules are generated by:
A. the Calvin cycle
B. chemiosmosis
C. the electron transport chain
D. light striking the chlorophyll molecules

29. The molecule that carries each amino acid to its correct position along mRNA in the cytoplasm is:
A. ribosomal RNA
B. TRNA
C. MRNA
D. ATP

30. We have all heard that dietary fats are linked to higher incidences of heart disease and cancer in humans. Choose the proper hypothesis that a scientist could test.

A. Eating more meat causes cancer.

B. Eating a diet of lard makes you fat.

C. Dietary fat, heart disease, and cancer are all somehow interrelated.

D. Fat levels above $30 \%$ of calories in the diet are correlated with an increase in heart disease. 
BSC 1005L Section\#:

Student Name:

Identification \#:

1. Gender: Female Male

2. Ethnic Group: Black Hispanic Asian/Pacific Islander American Indian White-non Hispanic Other

3. ESL (English is a second language): Yes No

4. College GPA (Grade Point Average): best estimate

5. BS1005: Completed Taking Now 


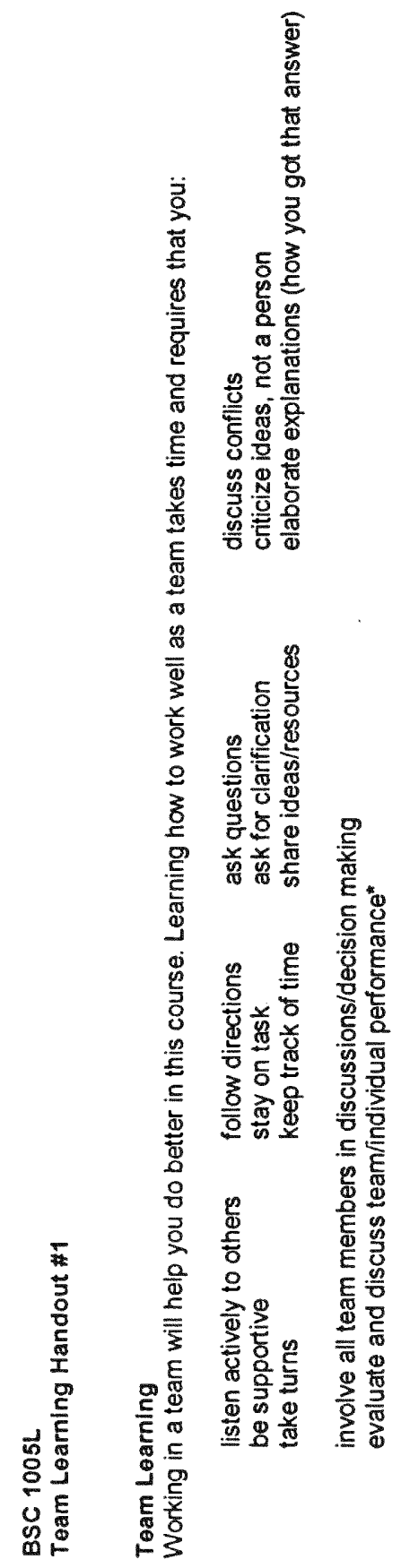

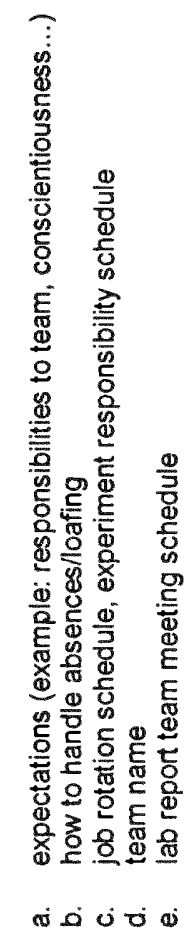

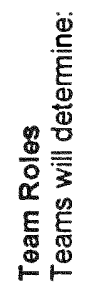

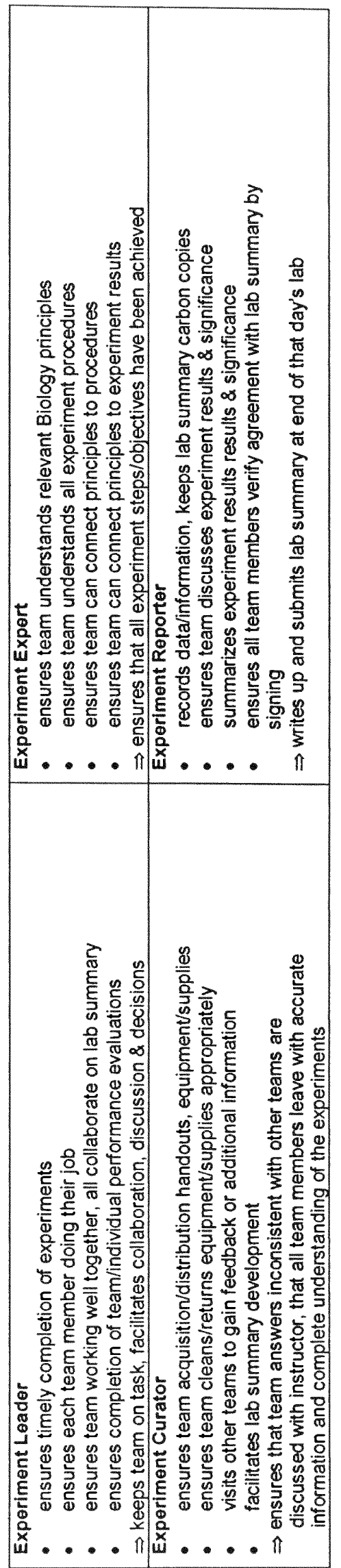


Appendix $\mathrm{E}$

BSC 1005L Section\#:

Team Performance Rating

Date:

Term $\| 97-8$

Rate as honestly as possible each of the following statements using the scale below:

5 strongly agree

4 agree

3 neither agree or disagree

2 disagree

1 strongly disagree

1. Everyone was prepared (read lab manual...).

Team:

Rater:

2. Everyone was encouraged to participate.

$\begin{array}{lllll}1 & 2 & 3 & 4 & 5\end{array}$

3. Everyone's comments were listened to and respected. $\begin{array}{lllll}1 & 2 & 3 & 4 & 5\end{array}$

4. Everyone stayed on task.

$\begin{array}{lllll}1 & 2 & 3 & 4 & 5\end{array}$

5. The quality of our laboratory summary was good.

$\begin{array}{lllll}1 & 2 & 3 & 4 & 5\end{array}$

Identify what you did today to help everyone understand what/why happened in the experiments?

Describe what could you do different to help your team work better during the next lab? 
BSC 1005L Section\#:

Trust Performance Self Rating

Date:
Term $\| 97-8$

Team:

Member:

Rate as honestly as possible each of the following statements using the scale below:

5 strongly agree

4 agree

3 neither agree or disagree

2 disagree

1 strongly disagree

1. I express my willingness to work with my team members and my expectation that they will also be helpful.

2. I share my information/resources with other team members to promote the success of individual members and the team as a whole.

3. I offer to help any team member who is having difficulty doing or understanding an experiment.

4. I communicate to other team members that I am aware of and appreciate their abilities, skills and helpfulness.

5. I provide facts/suggestions/relevant information and give my opinions/ideas to promote team discussion. 
B.S. Nutrition

Pratt Institute

Brooklyn, New York

$1975-1976$

Nutritionist

Brooklyn Hospital

Brooklyn, New York

$1976-1980$

Nutritionist

Brooklyn Kidney Center

Brooklyn, New York

1977

M.S. Nutrition

Columbia University

New York, New York

1980-1981

Nutritionist

New York Infirmary

New York, New York

1981-1982

Nutritionist

Nephrology Foundation of Brooklyn

Brooklyn, New York

1982-1984

Nutrition, Assistant Professor

City University of New York

Long Island City, New York

1985-1992

Nutrition, Assistant Professor Broward Community College

Davie, Florida

1994-Present

Biology, Adjunct Assistant Professor

Broward Community College

Pembroke Pines, Florida 